\title{
Differential Regulation of MeCP2 Phosphorylation in the CNS by Dopamine and Serotonin
}

\author{
Ashley N Hutchinson', Jie V Deng', Dipendra K Aryal' ${ }^{2}$, William C Wetsel ${ }^{1,2,3,4}$ and Anne E West ${ }^{*, 1}$ \\ 'Department of Neurobiology, Duke University Medical Center, Durham, NC, USA; ${ }^{2}$ Department of Psychiatry and Behavioral Sciences, Duke \\ University Medical Center, Durham, NC, USA; ${ }^{3}$ Mouse Behavioral and Neuroendocrine Analysis Core Facility, Duke University Medical Center, \\ Durham, NC, USA; ${ }^{4}$ Department of Cell Biology, Duke University Medical Center, Durham, NC, USA
}

\begin{abstract}
Systemic administration of amphetamine (AMPH) induces phosphorylation of MeCP2 at Ser42I (pMeCP2) in select populations of neurons in the mesolimbocortical brain regions. Because AMPH simultaneously activates multiple monoamine neurotransmitter systems, here we examined the ability of dopamine (DA), serotonin (5-HT), and norepinephrine (NE) to induce pMeCP2. Selective blockade of the DA transporter (DAT) or the 5-HT transporter (SERT), but not the NE transporter (NET), was sufficient to induce pMeCP2 in the CNS. DAT blockade induced PMeCP2 in the prelimbic cortex (PLC) and nucleus accumbens (NAc), whereas SERT blockade induced PMeCP2 only in the NAc. Administration of selective DA and 5-HT receptor agonists was also sufficient to induce pMeCP2; however, the specific combination of DA and 5-HT receptors activated determined the regional- and cell-type specificity of pMeCP2 induction. The $D_{1}$-class DA receptor agonist SKF8I297 induced PMeCP2 widely; however, coadministration of the $\mathrm{D}_{2}$-class agonist quinpirole restricted the induction of $\mathrm{PMeCP} 2$ to GABAergic interneurons of the NAc. Intra-striatal injection of the adenylate cyclase activator forskolin was sufficient to induce PMeCP2 in medium-spiny neurons, suggesting that the combinatorial regulation of cAMP by different classes of DA and 5-HT receptors may contribute to the cell-type specificity of pMeCP2 induction. Consistent with the regulation of PMeCP2 by multiple monoamine neurotransmitters, genetic disruption of any single monoamine transporter in DAT-, SERT-, and NETknockout mice failed to eliminate AMPH-induced PMeCP2 in the NAc. Together, these studies indicate that combinatorial signaling through DA and 5-HT receptors can regulate the brain region- and cell-type specific PMeCP2 in the CNS.

Neuropsychopharmacology (2012) 37, 321-337; doi: 10.1038/npp.201 I.190; published online 28 September 20I I
\end{abstract}

Keywords: MeCP2; monoamine transporters; signal transduction; dopamine; serotonin; nucleus accumbens

\section{INTRODUCTION}

Psychostimulant-induced activation of monoamine receptors is essential to the mechanism by which these drugs induce changes in behavior (Gainetdinov and Caron, 2003; Missale et al, 1998; Xu et al, 1997). Cocaine and amphetamine (AMPH) serve as indirect monoamine receptor agonists by inhibiting and/or reversing the function of monoamine transporters. However, despite the fact that these drugs rapidly increase extracellular levels of dopamine (DA), serotonin (5-HT), and norepinephrine (NE), repeated exposure is necessary to produce longlasting alterations in behavior (Hyman et al, 2006). This observation suggests that molecular mechanisms downstream of monoamine receptor activation are required to mediate the observed behavioral adaptations.

\footnotetext{
*Correspondence: Dr AE West, Department of Neurobiology, Duke University Medical Center, Box 3209, Durham, NC 27710, USA, Tel: + I 919681 1909, Fax: + 9196844431 ,

E-mail: west@neuro.duke.edu
}

Received 29 March 20 I I; revised 29 July 201 I; accepted 29 July 201 I
A substantial body of evidence indicates that psychostimulant-induced changes in gene expression contribute to the long-lasting effects of these drugs on behavior (Nestler, 2008; Kumar et al, 2005). Examination of the molecular processes underlying these changes in gene expression has revealed a significant role for epigenetic mechanisms of transcription, which are processes that mediate changes in gene expression by regulating chromatin structure (Maze et al, 2010; Renthal et al, 2009). Therefore, chromatin regulatory proteins that are targets of modulation by monoaminergic signaling pathways are strong candidates to link psychostimulant exposure to persistent changes in gene expression and behavior. Recently, we and others have demonstrated that the methyl-CpG-binding protein-2 (MeCP2) contributes to both neural and behavioral adaptations induced by repeated psychostimulant exposure (Deng et al, 2010; Im et al, 2010). We have shown that lentiviral shRNA-mediated knockdown of $\mathrm{MeCP} 2$ in the nucleus accumbens (NAc) increases sensitivity to AMPH-induced conditioned place-preference (CPP) whereas overexpression of MeCP2 decreases CPP (Deng et al, 2010). These data suggest that MeCP2 acts in the NAc to limit the rewarding properties of psychostimulants. 
Psychostimulants induce rapid and robust phosphorylation of MeCP2 at Ser421 (pMeCP2), a site that is thought to modulate MeCP2-dependent chromatin regulation (Deng et al, 2010; Zhou et al, 2006; Chen et al, 2003). MeCP2 regulates gene transcription by binding to methylated DNA and recruiting enzymes that modify histones (Nan et al, 1998). Although the specific mechanisms by which Ser421 phosphorylation affects $\mathrm{MeCP} 2$ function remain poorly understood, overexpression of a Ser421Ala mutant MeCP2 has been shown to inhibit neuronal activity-induced $B d n f$ expression, suggesting that Ser421 phosphorylation could contribute to gene derepression (Zhou et al, 2006). Interestingly, systemic administration of AMPH induces a restricted pattern of $\mathrm{pMeCP} 2$ induction in select neurons of the NAc and prelimbic cortex (PLC) (Deng et al, 2010). $\mathrm{D}_{1}$-class DA receptor activation is required for AMPHdependent induction of pMeCP2 in the NAc, and administration of a $D_{1}$-class DA receptor agonist is sufficient to induce pMeCP2 (Deng et al, 2010). However, AMPH induces pMeCP2 selectively in GAD67- and parvalbuminpositive GABAergic interneurons of the NAc whereas it fails to induce $\mathrm{pMeCP} 2$ in medium-spiny neurons (MSNs), despite the fact that these cells express high levels of DA receptors. In addition to its effects on DA neurotransmission, AMPH also impacts 5-HT and NE neurotransmission. Thus, we considered the possibility that the selective pattern of pMeCP2 induced by AMPH might arise as a result of combinatorial signaling through one or more of these monoaminergic systems.

Here, we use both pharmacological and genetic techniques to characterize the differential roles of DA, 5-HT, and $\mathrm{NE}$ signaling in the regulation of the regional distribution and cell-type specificity of pMeCP2 induction. We find that selective inhibition of either the DA transporter (DAT) or 5-HT transporter (SERT) but not the NE transporter (NET) is sufficient to induce pMeCP2 in the NAc. However, only DAT inhibition induces PMeCP2 in the PLC. We also find that differential activation of specific classes of DA and 5-HT receptors induces pMeCP2 in distinct cell types and brain regions, suggesting that combinatorial signaling through these receptors sculpts the specific pattern of pMeCP2 induction in vivo. Finally, we discuss potential functional roles for $\mathrm{pMeCP} 2$ based on our analyses of AMPH-induced pMeCP2 in DAT-, SERT-, and NET-knockout (KO) mouse strains, each of which has a distinct profile of behavioral responses to AMPH administration. Taken together, these data significantly enhance understanding of the mechanisms and consequences of monoaminergic regulation of $\mathrm{MeCP} 2$ in the CNS.

\section{MATERIALS AND METHODS}

\section{Animals}

Adult (8-10 week old) male C57BL/6 mice (Jackson Laboratories, Bar Harbor, ME), DAT, NET, vesicular monoamine transporter 2 (VMAT2) mice (provided by Dr Marc Caron at Duke University Medical Center, Durham, NC), and SERT mice (provided by Dr Scott Hall, NIDA, Bethesda, MD) were used in these studies. The wild-type (WT), heterozygous (HET), and KO littermates were generated from HET breedings. Animals were weaned at
21-30 days of age, housed in groups of 3-5, and segregated by sex and genotype. All animals were given free access to standard laboratory chow and water and were housed in a humidity- and temperature-controlled room on a 14-h/10-h light/dark cycle (lights on at 0700 hours). All experiments were conducted with an approved protocol from the Duke University Institutional Animal Care and Use Committee in accordance with the guidelines from the National Institutes of Health for the Care and Use of Laboratory Animals.

\section{Immunofluorescent Staining of the Brain Sections}

Two hours after vehicle or drug injection, mice were perfused transcardially with $4 \%$ paraformaldehyde in $0.1 \mathrm{M}$ PBS. The brains were post-fixed in $4 \%$ paraformaldehyde/PBS overnight, then sunk into $20 \%$ (wt/vol) sucrose/PBS overnight. Coronal sections $(40 \mu \mathrm{m})$ were cut on a freezing microtome, and the brain regions were identified by anatomical landmarks. One section from each brain region of interest was selected for each mouse, based upon anatomical structures to represent the closest approximation of identical sections between individual mice. To minimize technical variations in immunostaining across genotypes, sections from different individual mice were first photographed for visual identification. The sections were then pooled and incubated with antibodies in a single chamber, and finally they were separated after processing for image analysis (see Deng et al, 2010). For immunostaining, tissue sections were permeabilized with either $1 \%$ ( $\mathrm{vol} / \mathrm{vol}$ ) (for the pMeCP2 antibody) or $0.3 \%$ (vol/vol) (all other antibodies) Triton X100 for $1 \mathrm{~h}$ and then sections were blocked with $3 \%$ (wt/vol) BSA (for the DARPP-32 antibody) or $16 \%$ (vol/vol) goat serum (all other antibodies) in PBS. Sections were incubated with the following primary antibodies overnight at $4{ }^{\circ} \mathrm{C}$ : rabbit anti-phospho-Ser421 MeCP2 1:15000 (Deng et al, 2010), mouse anti-GAD67 1:500 (MAB5406; Chemicon/Millipore, Billerica, MA), rabbit anti-c-Fos 1:15000 (PC38; Calbiochem, San Diego, CA), goat anti-DARPP-32 1:50 (sc31519; Santa Cruz Biotechnology, Santa Cruz, CA), and mouse anti-GFAP 1:100 (Clone G-A-5; Sigma, St Louis, MO). Whenever possible, double immunostaining with primary antibodies raised in two different species was used for colocalization on single sections in order to determine the cell type in which pMeCP2 was induced. After three washes in PBS, sections were incubated with the following species-specific fluorescentconjugated secondary antibodies for $1 \mathrm{~h}$ at room temperature: goat anti-mouse antibodies conjugated to $\mathrm{Cy} 3$ or $\mathrm{Cy} 2$ 1:500 (Jackson Immunoresearch, West Grove, PA), Alexa Fluor 488 goat anti-rabbit antibodies at 1:500 (A11034; Molecular Probes/Invitrogen, Carlsbad, CA), Cy3 donkey anti-rabbit antibodies at 1:500 (Jackson Immunoresearch), or Alexa Fluor 488 donkey anti-goat antibodies (A11055; Molecular Probes/ Invitrogen). Sections were washed in PBS, nuclei were labeled with Hoechst dye (Sigma) to facilitate anatomical localization of the brain structures, sections were mounted and coverslipped, and analyzed as described below.

\section{Image Analyses}

For quantitative immunofluorescence, images were captured on a Leica DMI4000 inverted fluorescence microscope using a Cascade 512B camera. Digital images were quantified using 
MetaMorph 7 Image Analysis software (Molecular Devices, Sunnyvale, CA). To minimize variation between samples, images were captured with a uniform exposure time within a single experiment, and immunofluorescence was quantified across a constant-sized region from a single field of each section (as shown in Figure 1a). We used the Count Nuclei module in MetaMorph 7.0 to first count the total number of cells per section that were positive for $\mathrm{pMeCP} 2$ or c-Fos immunoreactivity and then we determined the integrated immunofluorescence intensity of all the pMeCP2 or c-Fospositive nuclei in each image. We defined nuclei as objects of $3-8 \mu \mathrm{m}$ in diameter. For each experiment, an investigator blind to genotype and treatment condition chose a random section from which to set a single threshold value of fluorescence intensity above background to score objects of this size as positive for $\mathrm{pMeCP} 2$ or c-Fos expression. The threshold value was adjusted until the program's output of detected nuclei most closely matched the distribution of positive nuclei seen by eye. This threshold value was then held constant for every image within the experimental set. The first result of this analysis is a count of the number of cells that are pMeCP2 or c-Fos positive in each image. The Count Nuclei module then creates a mask that covers the area of all of the nuclei identified as positive on each section and quantifies the total immunofluorescence intensity under this area (the 'integrated intensity') for each image. Thus, our analysis allows us to tell how many cells have induced expression of pMeCP2 or c-Fos in each image as well as to evaluate the magnitude of $\mathrm{pMeCP} 2$ or $\mathrm{c}$-Fos induction in these nuclei.
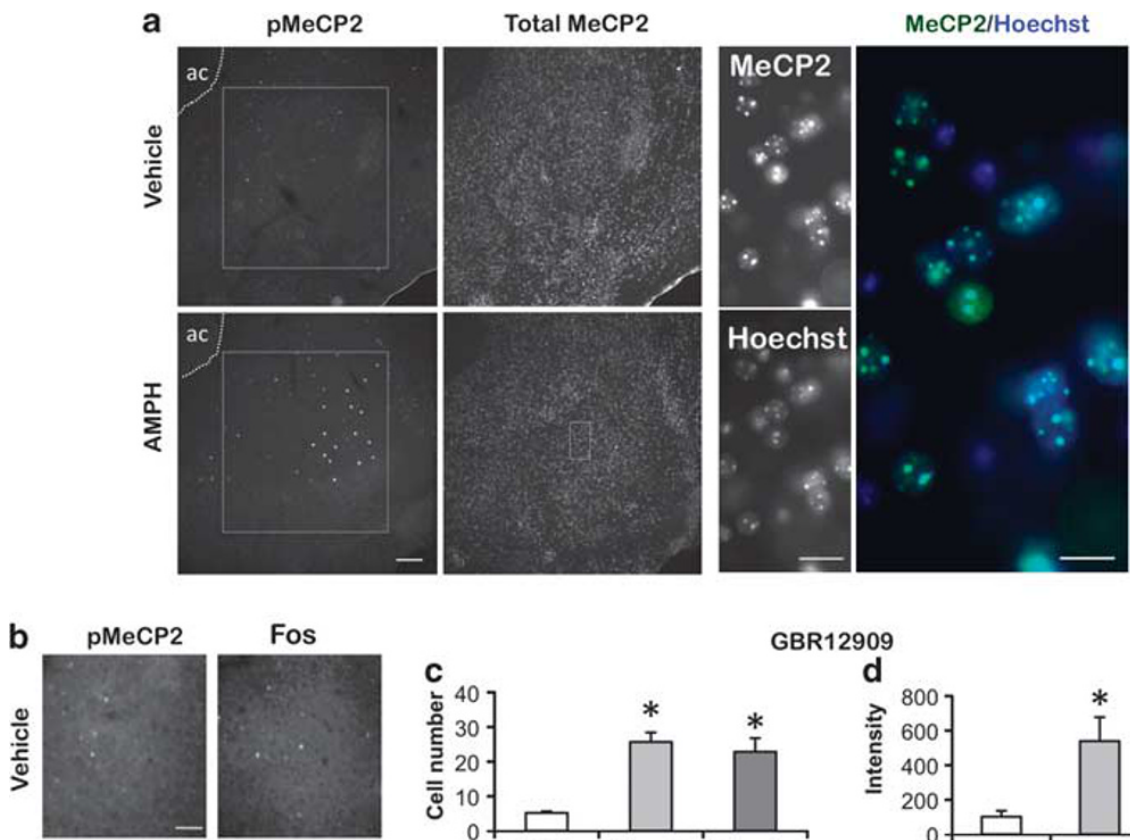

Fos
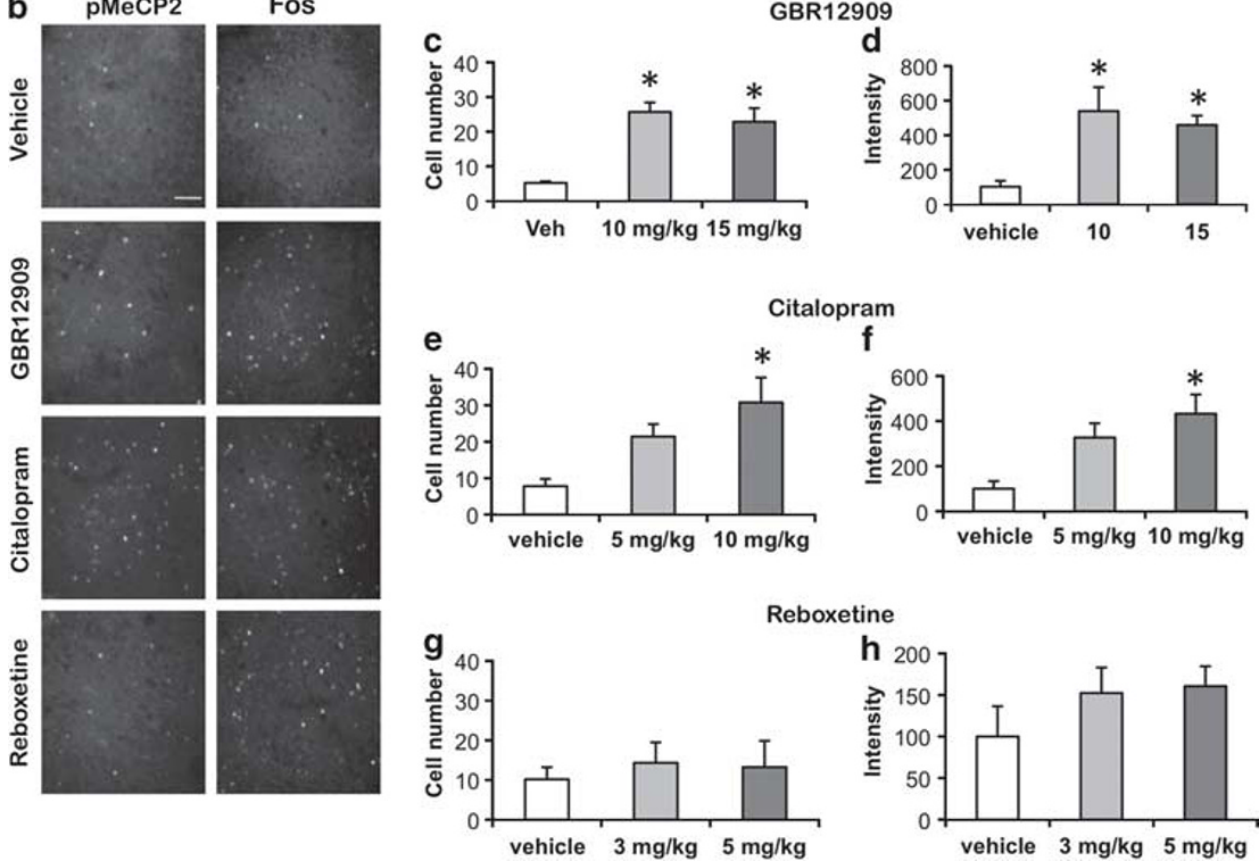

Figure I Selective DAT and SERT blockade differentially induces PMeCP2 in the NAc. (a) pMeCP2 and total MeCP2 induction following vehicle or $3 \mathrm{mg} / \mathrm{kg}$ AMPH injection. Solid gray box indicates representative section of NAc used to quantify pMeCP2 immunofluorescence. Dashed white box was used as the inset image to examine total MeCP2 and Hoechst (nuclear marker) overlay. ac, anterior commissure. (b) pMeCP2 immunostaining in the NAc (left column) and c-Fos immunostaining (right column) $2 \mathrm{~h}$ after treatment with Veh, $10 \mathrm{mg} / \mathrm{kg}$ GBRI2909, $10 \mathrm{mg} / \mathrm{kg}$ citalopram, or $3 \mathrm{mg} / \mathrm{kg}$ reboxetine. (c, e, g) number of cells in which pMeCP2 was induced following treatment of GBRI2909, citalopram, or reboxetine. (d, f, h) pMeCP2 integrated intensity in the NAc following treatment with GBRI2909, citalopram, or reboxetine. All values of quantitated immunofluorescence intensity were normalized to Veh control for each drug. $n=5-8$ mice/group. ${ }^{*} p<0.05$ compared with Veh. Error bars indicate SEM. Scale bars $=10 \mu \mathrm{m}$. 


\section{Bilateral Guide Cannula Surgery}

Mice were anesthetized with chloral hydrate $(400 \mathrm{mg} / \mathrm{kg}$ i.p.). A 22-gauge bilateral stainless steel guide cannula assembly with center-to-center distance of $2.0 \mathrm{~mm}$ (PlasticsOne, Raanoke, VA) was implanted over the striatum in both hemispheres. Stereotaxic coordinates relative to bregma were $\mathrm{A} / \mathrm{P}+1.42 \mathrm{~mm}, \mathrm{M} / \mathrm{L} \pm 1.0 \mathrm{~mm}$, $\mathrm{D} / \mathrm{V}-3.6 \mathrm{~mm}$. Guide cannulae were anchored to the skull using carboxylate dental cement (Durelon, CMA Microdialysis). A dust cap was placed over the entire cannula assembly. The mice were housed individually after surgery and allowed to recover for 8-9 days. Mice were treated with the antibiotic cotrimoxazole, $3 \% \mathrm{w} / \mathrm{v}$ solution in water, for the first 3 days following surgery.

\section{Intra-Striatal Infusions}

All infusions were performed in an empty cage that was the same dimensions as the home cage and were administered in freely moving mice. A 28-gauge stainless steel injector cannula with $3.6 \mathrm{~mm}$ length was used for all drug infusions. The injection cannula was attached to a $25-\mu$ l Hamilton syringe (Hamilton, Reno, NV). In all, $1 \mu \mathrm{l}$ of drug and saline was simultaneously infused into the left and right hemispheres over 6 min using a Razel infusion pump (Razel Scientific Instruments, St Albans, VT). The mice were infused with $2.5 \mu \mathrm{g} / \mu \mathrm{l}$ forskolin, 7-deacetyl-7-[0-( $\mathrm{N}$-methylpiperazino)-g-butryl]-dihydrochloride (Calbiochem, La Jolla, CA) in one hemisphere and vehicle (saline) in the other so that each mouse served as its own control. Side selection was randomized. Injection cannulae remained in place for an additional $2 \mathrm{~min}$ to allow drug diffusion and then a dummy cannula was inserted into the guide to prevent backflow. The mice were perfused transcardially with $4 \%$ paraformaldehyde $90 \mathrm{~min}$ after infusion.

\section{Striatal Cultures}

Whole striatum was dissected from embryonic day 17 CD-1 rats (Charles River Laboratories, Wilmington, MA), dissociated mechanically, and plated on PDL-coated dishes containing DMEM/F12 medium (Invitrogen) with B27 supplements (Invitrogen). After 5 days in culture, neurons were stimulated with the following drugs: $55 \mathrm{mM} \mathrm{KCl}$ in an isotonic solution (see Tao et al, 1998), $50 \mu \mathrm{M}$ NMDA (Sigma), $10 \mu \mathrm{M}$ forskolin (EMD, Gibbstown, NJ), or $50 \mu \mathrm{M}$ SKF38393 (Sigma). In some experiments, $5 \mu \mathrm{M}$ Nimodipine (Sigma) or $100 \mu \mathrm{M}$ APV (Tocris) was added 2 min before stimulation with $\mathrm{KCl}$ or NMDA. Sixty minutes after stimulation, cells were lysed in boiling SDS-PAGE sample buffer for analysis of protein phosphorylation by western blotting. In addition to the MeCP2 antibodies described above, the following antibodies were used: rabbit antiCREB 1:1000 (06-863; Upstate Biotechnology/Millipore), mouse anti-phospho-Ser133 CREB 1:1000 (05-667; Upstate Biotechnology/Millipore), goat anti-rabbit-HRP 1:10 000 (Jackson Immunoresearch), and goat anti-mouse-HRP 1:10 000 (Jackson Immunoresearch).

\section{Locomotor Activity in the Open Field}

Mice were habituated to the open field (Accuscan Instruments, Columbus, $\mathrm{OH}$ ) for $1 \mathrm{~h}$ to establish baseline activity and then injected with vehicle (Veh) or $3 \mathrm{mg} / \mathrm{kg}$ AMPH (Sigma), $5 \mathrm{mg} / \mathrm{kg}$ SFK81297 (Tocris Bioscience, Ellisville, MO), $0.25 \mathrm{mg} / \mathrm{kg}$ quinpirole (Tocris), 5 or $10 \mathrm{mg} / \mathrm{kg}$ citalopram (Tocris), 10 or $15 \mathrm{mg} / \mathrm{kg}$ GBR12909 (Tocris), 3 or $5 \mathrm{mg} / \mathrm{kg}$ reboxetine (Tocris), or 3 or $4.5 \mathrm{mg} / \mathrm{kg}$ quipazine (Tocris). All injections were i.p., and all drugs were dissolved in sterile water, except SKF81297, which was dissolved in DMSO (final concentration $0.5 \% \mathrm{vol} / \mathrm{vol}$ ). Following administration of Veh or drug, animals were immediately returned to the open field for $1 \mathrm{~h}$. Horizontal (distance traveled in $\mathrm{cm}$ ) was monitored under 340 lux illumination.

\section{Behavioral Sensitization}

Two different protocols were used as referenced in the text. In the first protocol, mice were injected with Veh or $3 \mathrm{mg} / \mathrm{kg}$ AMPH once a day for 5 consecutive days in the home cage, they were withdrawn from drug for 7 days, then they were challenged with $3 \mathrm{mg} / \mathrm{kg}$ AMPH in the open field while horizontal activity (distance traveled in $\mathrm{cm}$ ) was monitored as described in the 'Locomotor Activity in the Open Field' section above. In the second protocol, the first injection of vehicle or AMPH was given in the open field so that locomotor activity could be recorded. The mice were then returned to the home cage where they received daily injections of Veh or $3 \mathrm{mg} / \mathrm{kg}$ AMPH for 4 additional consecutive days. The mice were then withdrawn from drug for 7 days, then they were challenged with $3 \mathrm{mg} / \mathrm{kg}$ AMPH in the open field while horizontal activity (distance traveled in $\mathrm{cm}$ ) was monitored.

\section{Statistical Analyses}

Statistical analyses were performed using SPSS v11.0 statistical software (SPSS, Chicago, IL). The data are depicted as mean values and standard errors of the mean (SEM). The pMeCP2 immunoreactivities and locomotor activities of the transporter KO mice given Veh or AMPH were analyzed using two-way ANOVA for genotype and treatment. Activities of the mice were aggregated over the 1-h post-injection period. For C57BL/6J mice injected with Veh, GBR12909, citalopram, reboxetine, SKF81297, quinpirole, SKF81297 + quinpirole, quinpirole alone, or quipazine, pMeCP2 immunoreactivities in the NAc were analyzed using univariate ANOVA for treatment condition. Bonferroni corrected pairwise comparisons were used as the post hoc tests. Induction of Fos and $\mathrm{pMeCP} 2$ by intra-striatal forskolin was assessed by a Student's unpaired $t$-test. We assessed the correlation between $\mathrm{pMeCP} 2$ immunoreactivity and locomotor activity with Pearson correlation coefficients. In all cases, $p<0.05$ was considered statistically significant.

\section{RESULTS}

\section{Selective Blockade of the DAT or SERT Is Sufficient to Induce $\mathrm{pMeCP} 2$}

Pharmacological targets of AMPH in the CNS include the DAT, SERT, and NET plasma membrane transporters, as well as the VMAT2 vesicular transporter (Fleckenstein et al, 
Table I Changes in Locomotor Activity Following Acute DAT, SERT, or NET Blockade

\begin{tabular}{lccc}
\hline Drug & $\begin{array}{c}\text { Distance } \\
\mathbf{( c m}) \text { Veh }\end{array}$ & $\begin{array}{c}\text { Distance } \\
(\mathbf{c m}) \text { dose } \mathbf{~}\end{array}$ & $\begin{array}{c}\text { Distance } \\
(\mathbf{c m}) \text { dose 2 }\end{array}$ \\
\hline GBRI2909 & $3390.3 \pm 66.2$ & $13645.6 \pm 1627.6 *$ & $12482.4 \pm 2153.6^{*}$ \\
Citalopram & $3946.6 \pm 690.1$ & $2514.2 \pm 407.9$ & $729.0 \pm 241.9^{*}$ \\
Reboxetine & $1727.5 \pm 96.1$ & $1036.2 \pm 277.8$ & $747.8 \pm 118.8^{*}$
\end{tabular}

The effects of 10 or $15 \mathrm{mg} / \mathrm{kg}$ GBRI2909, 5 or $10 \mathrm{mg} / \mathrm{kg}$ citalopram, and 3 or $5 \mathrm{mg} / \mathrm{kg}$ reboxetine on locomotor activity in C57BL/6 mice I h post-injection. Dose I=lower dose; dose 2 =higher dose. All values of locomotor activity were normalized to Veh control for each drug. $n=6-8$ mice/group.

* $p<0.05$ compared with Veh. Error bars indicate SEM.

2007; Han and Gu, 2006; Sulzer et al, 2005). Through its interactions with these target proteins, AMPH simultaneously raises extracellular levels of multiple monoamine neurotransmitters. To address the contributions of single monoaminergic neurotransmitter systems to the regulation of MeCP2 phosphorylation, we evaluated the ability of selective monoamine transporter inhibitors to induce pMeCP2 in the NAc (Figure 1). C57BL/6 mice were administered either Veh, a DAT inhibitor (GBR12909, $10 \mathrm{mg} / \mathrm{kg}$ or $15 \mathrm{mg} / \mathrm{kg}$ ), a SERT inhibitor (citalopram, $10 \mathrm{mg} / \mathrm{kg}$ or $15 \mathrm{mg} / \mathrm{kg}$ ), or a NET inhibitor (reboxetine, $3 \mathrm{mg} / \mathrm{kg}$ or $5 \mathrm{mg} / \mathrm{kg}$ ). Open field locomotor activity was monitored for $1 \mathrm{~h}$ then the mice were perfused $2 \mathrm{~h}$ postinjection to assess pMeCP2 immunoreactivity. For GBR12909, an ANOVA for locomotor activity revealed a significant effect of treatment $\left(\mathrm{F}_{2,15}=13.313, p<0.001\right)$. Both doses of GBR12909 significantly increased locomotor activity compared with mice treated with Veh ( $p$-value$\mathrm{s}<0.004$ ) (Table 1). For pMeCP2 immunoreactivity in mice treated with GBR12909, an ANOVA indicated a significant effect of treatment $\left(\mathrm{F}_{2,14}=12.083, p<0.001\right)$, and Bonferroni comparisons showed that $\mathrm{pMeCP} 2$ intensities in both the $10-$ and $15-\mathrm{mg} / \mathrm{kg}$ groups were significantly higher than the Veh group ( $p$-values $<0.05$ ) (Figure $1 \mathrm{~b}-\mathrm{d}$ ). These data demonstrate that selective blockade of the DAT is sufficient to induce $\mathrm{pMeCP} 2$ in the NAc.

ANOVA for locomotor activity in citalopram-treated mice revealed a significant effect of treatment $\left(\mathrm{F}_{2,16}=13.02\right.$, $p<0.001)$. Unlike GBR12909, citalopram treatment led to a reduction in locomotor activity, although $10 \mathrm{mg} / \mathrm{kg}$ was the only dose to significantly lower activity $(p<0.001)$ (Table 1$)$. When changes in pMeCP2 induction were considered for citalopram-treated mice, the ANOVA detected a significant effect of treatment $\left(\mathrm{F}_{2,16}=4.236, p<0.04\right)$, post hoc analyses found that the $\mathrm{pMeCP} 2$ intensity was significantly higher than the Veh group only for the $10-\mathrm{mg} / \mathrm{kg}$ dose $(p<0.05)$ (Figure $1 \mathrm{~b}, \mathrm{e}$, and $\mathrm{f}$ ). These data demonstrate that selective blockade of the SERT is also sufficient to induce pMeCP2 in the NAc. Intriguingly, we note that while GBR12909 and citalopram have opposite effects on locomotor activity, both drugs lead to the induction of pMeCP2 in the NAc. We discuss the relationship between pMeCP2 phosphorylation and locomotor activity further in the Discussion section.

Finally, inspection of the ANOVA for locomotor activity of mice treated with reboxetine revealed a significant effect of treatment $\left(\mathrm{F}_{2,16}=4.317, p<0.041\right)$. Like citalopram, reboxetine treatment led to a dose-dependent reduction in locomotor activity; only $5 \mathrm{mg} / \mathrm{kg}$ reboxetine significantly reduced locomotor activity compared with Veh-treated controls $(p<0.048)$ (Table 1). In contrast to the effects of GBR12909 and citalopram, pMeCP2 immunoreactivity in reboxetine-treated mice did not show an overall effect of treatment $\left(F_{2,16}=0.806, p<0.463\right)$, suggesting that activation of $\mathrm{NE}$ signaling is not sufficient to induce pMeCP2 in this context (Figure 1b, g, and h). In order to ensure that the failure to induce pMeCP2 was not due to improper selection of doses, we also examined the ability of each of these drugs to induce c-Fos expression. In all, $5 \mathrm{mg} / \mathrm{kg}$ reboxetine induced expression of c-Fos in the NAc to a similar extent as that seen following administration of $3 \mathrm{mg} / \mathrm{kg} \mathrm{AMPH}$, $10 \mathrm{mg} / \mathrm{kg}$ GBR12909, and $10 \mathrm{mg} / \mathrm{kg}$ citalopram. Hence, the doses of reboxetine used in this study are able to induce a transcriptional response in neurons of the NAc (Figure 1b) (Miyata et al, 2005). Together, these data show that selective activation of either DA or 5-HT but not NE signaling is sufficient to drive induction of pMeCP2 in the NAc.

Although most neurons within the NAc express MeCP2, we have shown that AMPH selectively induces PMeCP2 in a specific population of GABAergic interneurons that express the GABA synthesizing enzyme GAD67 and the calciumbinding protein parvalbumin (Deng et al, 2010). To determine whether selective monoamine transporter blockade can recapitulate this cell-type specificity of AMPHinduced $\mathrm{pMeCP} 2$, we colabeled NAc sections from mice treated with the selective transporter blockers with antibodies against both pMeCP2 and GAD67. Like AMPH, GBR12909 induced pMeCP2 only in GAD67-positive GABAergic interneurons of the NAc (Figure 2). However, examination of double-immunolabeled sections following citalopram administration revealed that the induced pMeCP2 is not restricted to this cell population.

AMPH-induced phosphorylation of MeCP2 is most robust in the NAc; however, AMPH drives a small, but statistically significant increase in pMeCP2 in the PLC (Deng et al, 2010). To determine which monoamine neurotransmitters are sufficient to induce pMeCP2 in this brain region, we asked whether GBR12909, citalopram, or reboxetine induced pMeCP2 in the PLC (Figure 3). ANOVA revealed a significant effect of treatment with GBR12909 $\left(\mathrm{F}_{2,14}=5.667, p<0.02\right) ; 10 \mathrm{mg} / \mathrm{kg}$ led to increased $\mathrm{pMeCP} 2$ induction compared with Veh controls $(p<0.02)$ (Figure 3a). Unlike GBR12909, citalopram or reboxetine failed to induce $\mathrm{pMeCP} 2$ in the PLC, despite the fact that citalopram induced $\mathrm{pMeCP} 2$ in the NAc of the same animals (Figures $3 \mathrm{~b}$ and $\mathrm{c}$ and $1 \mathrm{f}$, respectively). These data suggest that there is a selective role for $\mathrm{DA}$ in $\mathrm{pMeCP} 2$ induction in the PLC. Examination of PLC sections double immunolabeled for pMeCP2 and GAD67 revealed that the GBR12909-induced pMeCP2 in the PLC was not restricted to GAD67-positive GABAergic interneurons (Figure 3d). Taken together, these data indicate that DA and 5-HT play selective roles in the induction of $\mathrm{pMeCP} 2$ in different the brain regions and cell types.

\section{DA and 5-HT Receptor Agonists Differentially Induce pMeCP2}

Because selective inhibition of the DAT and SERT transporters is sufficient to drive $\mathrm{pMeCP} 2$, we next asked 

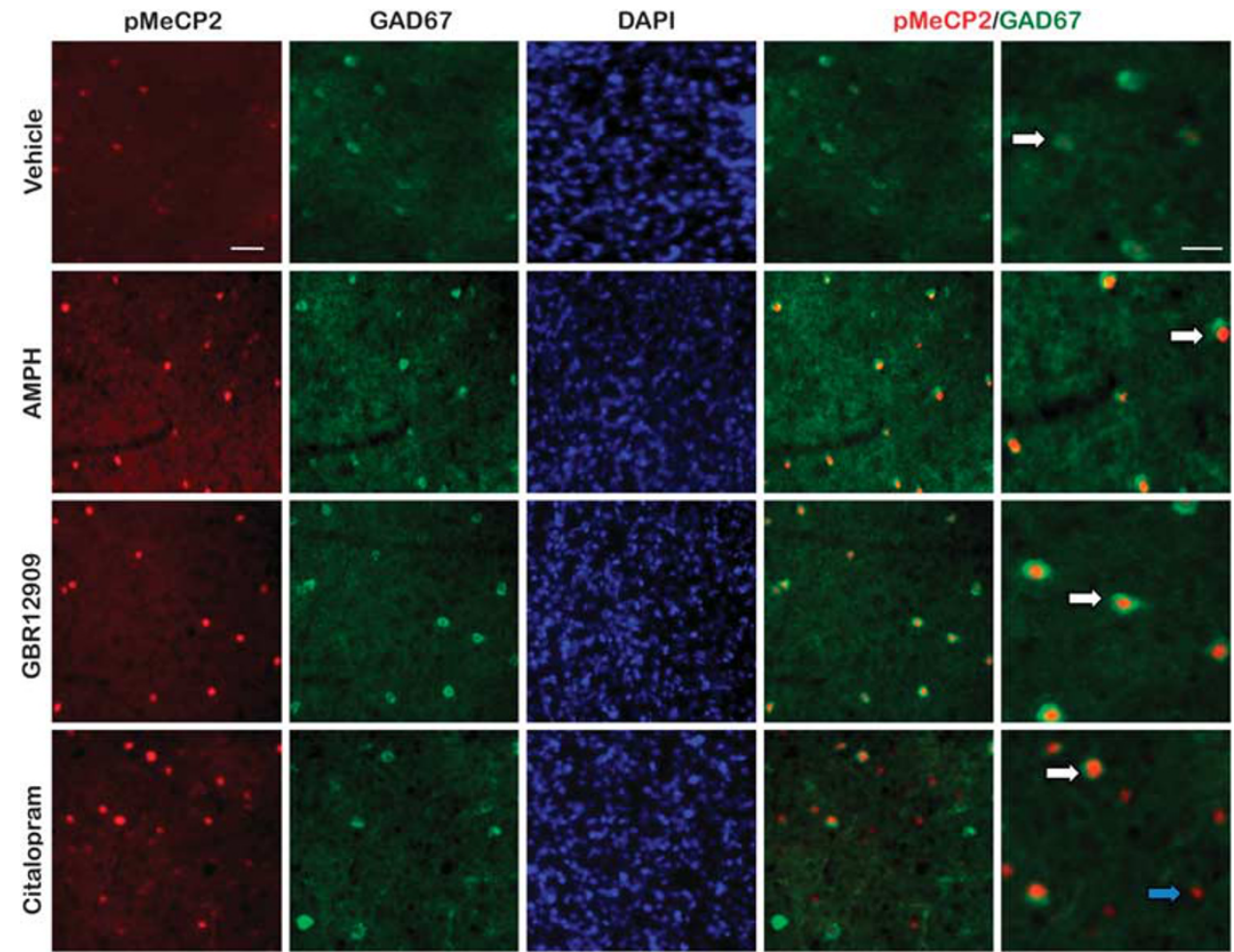

Figure 2 DAT and SERT blockers differentially regulate the cell-type specificity of MeCP2 phosphorylation in the NAc. pMeCP2 (red), GAD67 (green), Hoechst nuclear dye (blue), and overlay immunostaining in the NAc $2 \mathrm{~h}$ after treatment with Veh, $3 \mathrm{mg} / \mathrm{kg}$ AMPH, $10 \mathrm{mg} / \mathrm{kg}$ GBRI2909, or $10 \mathrm{mg} / \mathrm{kg}$ citalopram. White arrows indicate neurons coimmunolabeled with antibodies for pMeCP2 and GAD67, and blue arrows indicate pMeCP2 induction in neurons that are not GAD67-positive GABAergic interneurons. Scale bar $=20 \mu \mathrm{m}$.

which DA and 5-HT receptor subtypes mediate this response. DA acts through both $\mathrm{D}_{1^{-}}\left(\mathrm{D}_{1}\right.$ and $\left.\mathrm{D}_{5}\right)$ and $\mathrm{D}_{2}$-class $\left(\mathrm{D}_{2}, \mathrm{D}_{3}\right.$, and $\left.\mathrm{D}_{4}\right)$ receptors (Missale et al, 1998). Previously, we showed that SKF81297, a $\mathrm{D}_{1}$-class receptor agonist, is sufficient to drive robust phosphorylation of $\mathrm{MeCP} 2$ in the NAc (Deng et al, 2010). To determine the magnitude and regional distribution of $\mathrm{pMeCP} 2$ following $\mathrm{D}_{1}$-class receptor activation, $\mathrm{C} 57 \mathrm{BL} / 6 \mathrm{~J}$ mice were treated with 5 or $7.5 \mathrm{mg} / \mathrm{kg}$ SKF81297. To examine pMeCP2 induction following activation of $\mathrm{D}_{2}$-class receptors, pMeCP2 levels were quantified following treatment with quinpirole $(0.4 \mathrm{mg} / \mathrm{kg})$, a $\mathrm{D}_{2}$-class receptor agonist. Finally, because AMPH activates both $\mathrm{D}_{1^{-}}$and $\mathrm{D}_{2}$-class receptors simultaneously, we examined how combinatorial DA receptor activation influenced the level and distribution of pMeCP2 induction by coinjecting SKF81297 $(7.5 \mathrm{mg} / \mathrm{kg})$ and quinpirole $(0.4 \mathrm{mg} / \mathrm{kg})$.

When an ANOVA was applied to pMeCP2 immunoreactivity in the NAc following administration of Veh, SKF81297 $(7.5 \mathrm{mg} / \mathrm{kg})$, quinpirole, or coinjection of SFK81297 + quinpirole, an overall effect of treatment was observed $\left(\mathrm{F}_{3,16}=22.3, p<0.001\right)$. SKF81297 led to higher levels of pMeCP2 induction compared with Veh controls $(p<0.001)$. Parenthetically, activation of $\mathrm{D}_{1}$-class receptors alone led to more widespread induction of $\mathrm{pMeCP} 2$ than we observed following AMPH, both in the NAc, PLC, and most notably in the hippocampus, where we have not observed any AMPH-induced pMeCP2 (Figure 4a-c). Furthermore, upon examining the cell types in which pMeCP2 is induced within the NAc following injection of $7.5 \mathrm{mg} / \mathrm{kg}$ SKF81297, we find that unlike $A M P H$, the $D_{1}$-class receptor agonist induces pMeCP2 in both GAD67-positive interneurons and additional cell types (Figure 4d). These data suggest that additional AMPH-activated receptor systems may antagonize the effects of $D_{1}$-class signaling on the regional and cell-type specific induction of pMeCP2. One candidate for inhibition is $\mathrm{D}_{2}$-class receptors, which can be activated by the agonist quinpirole. Treatment of mice with $0.4 \mathrm{mg} / \mathrm{kg}$ quinpirole alone leads to a small induction of pMeCP2 that is confined to the GABAergic interneurons of the NAC (Figure $4 \mathrm{a}, \mathrm{b}$, and $\mathrm{d}$ ). Intriguingly, coinjection of this $\mathrm{D}_{2}$-class receptor agonist significantly reduces the extent of SKF81297-induced pMeCP2 both in the NAc $(p<0.001)$ (Figure 4b), as well as in the hippocampus (Figure 4c). Furthermore, coinjection of SKF81297 and quinpirole restricts the induction of $\mathrm{pMeCP} 2$ in the NAc to the GABAergic interneurons (Figure 4d). These data are consistent with the known mechanism of action of AMPH on both $\mathrm{D}_{1^{-}}$and $\mathrm{D}_{2}$-classes of receptors, and they suggest that combinatorial $\mathrm{D}_{1}$ - and $\mathrm{D}_{2}$-class receptor signaling may restrict the pattern and extent of AMPH-induced pMeCP2 to a select population of neurons within the NAc.

In addition to examining induction of pMeCP2 following activation of DA receptors, we also wanted to investigate the pattern of $\mathrm{pMeCP} 2$ produced by stimulation of $5-\mathrm{HT}$ receptors. There are 145 -HT receptor subtypes, which comprise seven different classes of receptors (Barnes and Sharp, 1999). Since 5- $\mathrm{HT}_{2}$ and $5-\mathrm{HT}_{3}$ receptors are highly expressed in the NAc, we asked whether administration of quipazine ( 3 or $4.5 \mathrm{mg} / \mathrm{kg}$ ), a $5-\mathrm{HT}$ receptor agonist that 

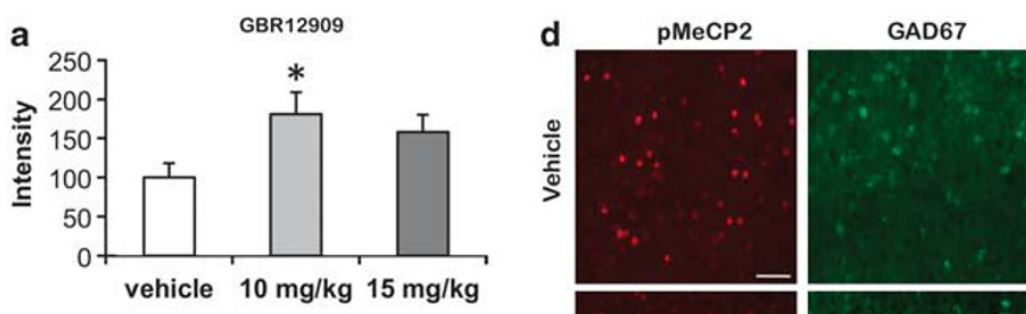

pMeCP2/GAD67
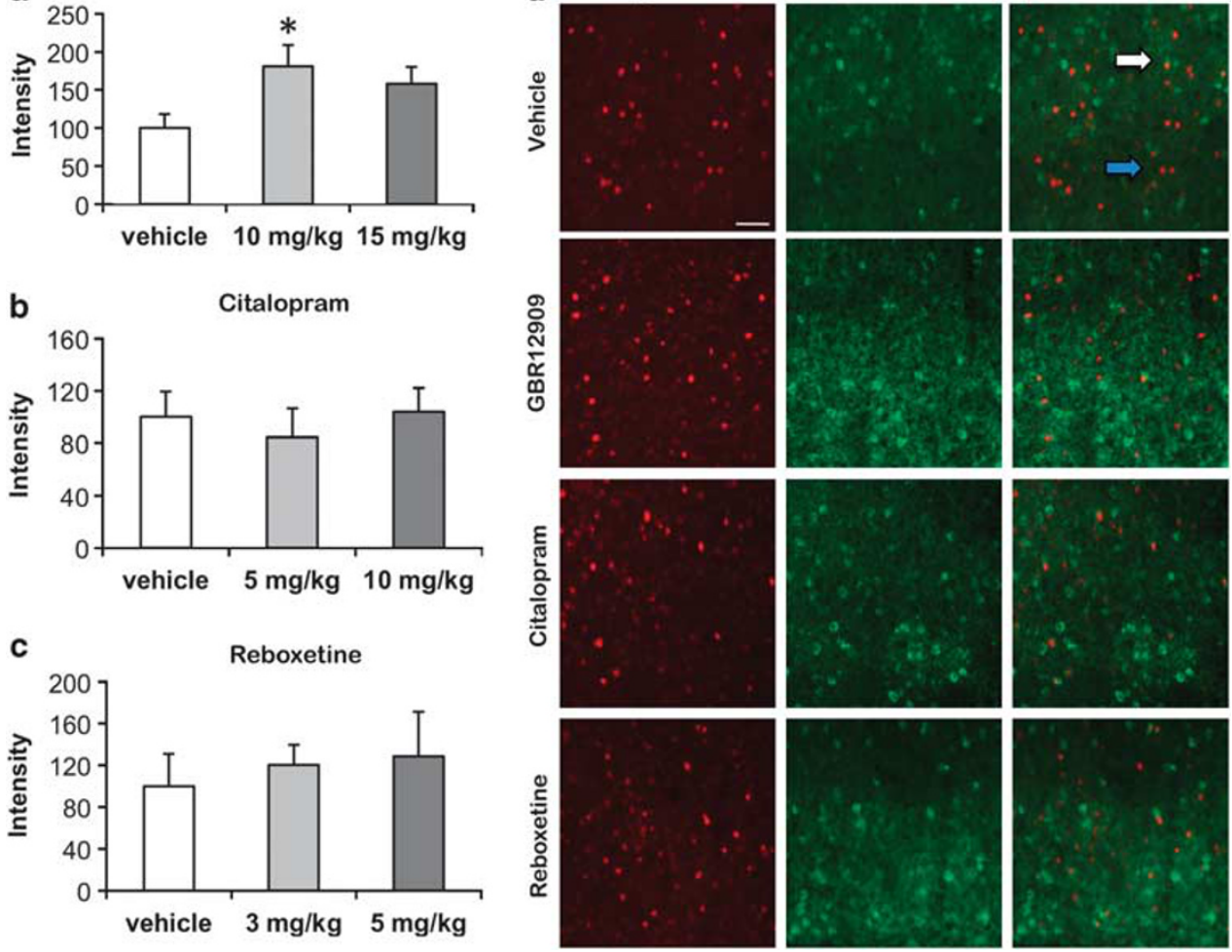

Figure 3 Selective DAT blockade induces pMeCP2 in the PLC. (a-c) pMeCP2 integrated intensity in the PLC following treatment with GBRI2909, citalopram, or reboxetine. All values of quantified immunofluorescence intensity were normalized to Veh control for each drug. (d) pMeCP2 (red), GAD67 (green), and overlay immunostaining in the PLC $2 \mathrm{~h}$ after treatment with Veh, $10 \mathrm{mg} / \mathrm{kg}$ GBRI2909, $10 \mathrm{mg} / \mathrm{kg}$ citalopram, or $3 \mathrm{mg} / \mathrm{kg}$ reboxetine. White arrows indicate neurons coimmunolabeled with antibodies for PMeCP2 and GAD67, and blue arrows indicate pMeCP2 induction in neurons that are not GAD67-positive GABAergic interneurons. $n=5-7$ mice/group. $* p<0.05$ compared with Veh. Error bars indicate SEM. Scale bars $=20 \mu \mathrm{m}$.

shows preferential activation of $5-\mathrm{HT}_{2}$ and $5-\mathrm{HT}_{3}$ receptors, can induce pMeCP2. ANOVA revealed a significant effect of treatment with quipazine $\left(\mathrm{F}_{2,9}=7.898, p<0.01\right)$. Both 3 and $4.5 \mathrm{mg} / \mathrm{kg}$ quipazine drove significant induction of pMeCP2 in the NAc, and these effects were restricted to the GABAergic interneurons $(p$-values $<0.05)$ (Figure $5 \mathrm{a}$ and $\mathrm{b})$. We note that the cell-type specific induction of pMeCP2 in the NAc following quipazine is in contrast to the pattern of phosphorylation following administration of the indirect agonist citalopram, which can activate signaling at all 14 5-HT receptor subtypes and which leads to induction of pMeCP2 that is more widespread (Figure 3). Together, these data suggest that different classes of DA and 5-HT receptors may have distinct effects on the pattern of pMeCP2 induction in the NAc.

Among the pharmacological reagents tested here, we saw the most widespread induction of $\mathrm{pMeCP} 2$ following administration of a $D_{1}$-class $D A$ receptor agonist. By contrast, a $\mathrm{D}_{2}$-class $\mathrm{DA}$ receptor agonist opposed the effects of $\mathrm{D}_{1}$-class receptor induction of $\mathrm{pMeCP} 2$. Because $\mathrm{D}_{1}$-class receptors are coupled through $\mathrm{G}_{\mathrm{s}}$ to increases in intracellular cAMP whereas $\mathrm{D}_{2}$-class receptors oppose the increase in cAMP through $\mathrm{G}_{\mathrm{i}}$, we considered the possibility that differential regulation of $\mathrm{pMeCP} 2$ by distinct $\mathrm{DA}$ and 5-HT receptors could be integrated at the level of cAMP signaling. To test whether the elevation of cAMP is sufficient to induce $\mathrm{pMeCP} 2$ in vivo, we infused the adenylate cyclase activator forskolin directly into the striatum of $\mathrm{C} 57 \mathrm{BL} / 6 \mathrm{~J}$ mice.
All sections selected for staining had similar cannula placement (Figure 6a). Compared with saline infusion, forskolin robustly induced expression of the cAMPregulated immediate early gene product Fos in neurons below the tip of the cannula, demonstrating the efficacy of the drug treatment $(p<0.01)$ (Figure $6 \mathrm{~b}$ and $\mathrm{c}$ ). Similarly, we found that forskolin infusion was sufficient to induce pMeCP2 $(p<0.05)$ (Figure $6 \mathrm{~b}$ and d). Unlike the sparse pattern of pMeCP2 induced by systemic AMPH administration (Figure 1), intra-striatal forskolin induced pMeCP2 in most of the cells near the cannula tip. This forskolininduced pMeCP2 colocalized in cells with DARPP-32, a marker of MSNs, and showed no overlap with GFAP, an abundantly expressed marker of glial cells (Figure 6e). Thus, these data show that intra-striatal forskolin delivery is sufficient to induce pMeCP2 in MSNs.

Forskolin infusion into the striatum could drive pMeCP2 by activating postsynaptic signaling cascades that directly induce MeCP2 phosphorylation in MSNs. Alternatively, because forskolin can act on presynaptic terminals to enhance the probability of neurotransmitter release (Chen and Regehr, 1997; Chavez-Noriega and Stevens, 1994) the induction of pMeCP2 in MSNs could be an indirect consequence of forskolin-induced release of neurotransmitter from the terminals of neurons that project to the striatum from other brain regions. To determine whether forskolin can act in MSNs to induce pMeCP2, we isolated the striatum from embryonic rat brains and treated 
a

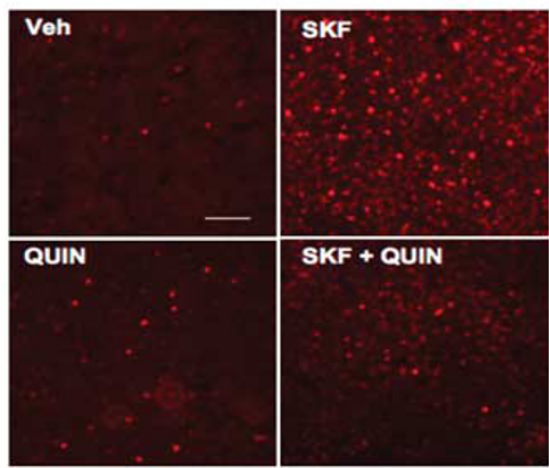

b

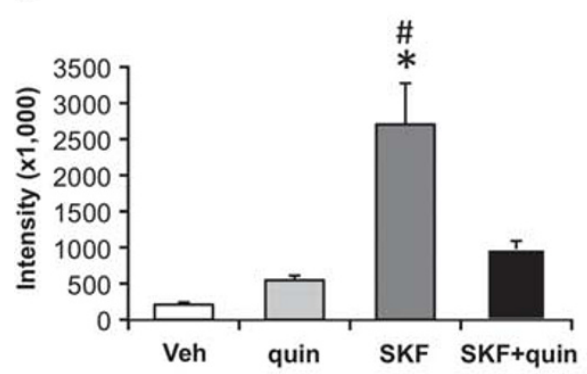

c

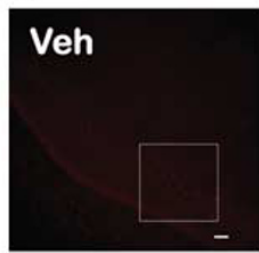

Enlargement
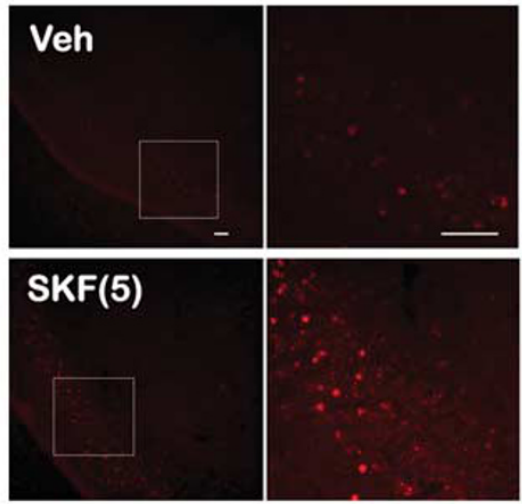

d

pMeCP2
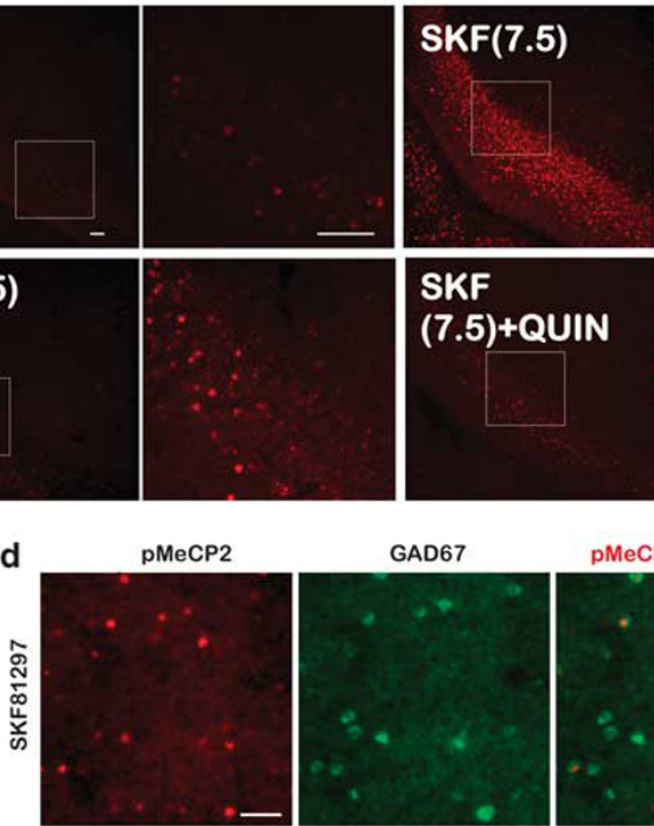

Enlargement
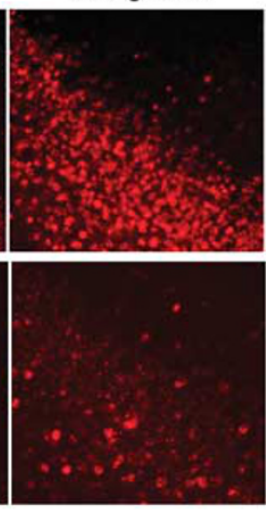

pMeCP2/GAD67

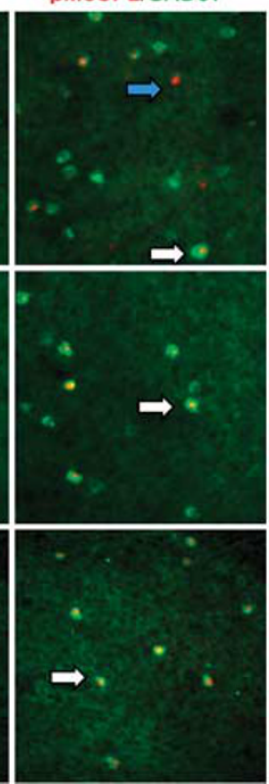

Figure 4 Stimulation of $D_{1}$ - and $D_{2}$-class $D A$ receptors induces different patterns of pMeCP2. (a) pMeCP2 immunostaining in the NAc $2 \mathrm{~h}$ after treatment with Veh, $7.5 \mathrm{mg} / \mathrm{kg}$ SKF8I297, $0.4 \mathrm{mg} / \mathrm{kg}$ quinpirole, or coinjection of SKF8I 297 and quinpirole. (b) Quantitation of pMeCP2 immunostaining from (a). (c) pMeCP2 induction in the hippocampus $2 \mathrm{~h}$ after treatment with Veh, 5 or $7.5 \mathrm{mg} / \mathrm{kg}$ SKF8I 297 , or coinjection of $7.5 \mathrm{mg} / \mathrm{kg}$ SKF8I297 and quinpirole. Enlargement images show the dotted inset regions. (d) pMeCP2 (red), GAD67 (green), and overlay immunostaining in the NAc $2 \mathrm{~h}$ after treatment with $7.5 \mathrm{mg} / \mathrm{kg}$ SKF8 $297,0.4 \mathrm{mg} / \mathrm{kg}$ quinpirole, or coinjection of SKF8I297 and quinpirole. White arrows indicate neurons coimmunolabeled with antibodies for pMeCP2 and GAD67, and blue arrows indicate pMeCP2 induction in neurons that are not GAD67-positive GABAergic interneurons. $n=4-7$ mice/group. ${ }^{*} p<0.05$ compared with Veh, $\# p<0.05$ SKF compared with SKF + quinpirole. Error bars indicate SEM. Scale bar $=20 \mu$ m.

dissociated cultures of striatal neurons with either forskolin or the $\mathrm{D}_{1}$-class DA receptor agonist SKF38393. Although these treatments induced phosphorylation of the protein kinase A (PKA) target and transcription factor CREB at Ser133, elevation of cAMP in cultured striatal neurons was not sufficient to induce pMeCP2 (Figure 6f). By contrast, both membrane depolarization and NMDA application induced $\mathrm{pMeCP} 2$ in these neurons in a manner that was dependent on the activation of L-type voltage-gated calcium channels and NMDA-type glutamate receptors, respectively (Figure $6 \mathrm{~g}$ ). We cannot rule out that the inability of forskolin to activate $\mathrm{pMeCP} 2$ in cultured MSNs is not a consequence of the immaturity of these cells. Nonetheless, taken all together, our data suggest that the differential ability of specific DA and 5-HT receptor agonists to drive pMeCP2 in MSNs (1) is integrated at the level of cAMP signaling and (2) may depend, at least in part, on presynaptic cAMP-dependent effects.

\section{AMPH-Induced pMeCP2 Is Reduced in SERT-KO Mice}

The data presented thus far have addressed the sufficiency of activating specific monoamine neurotransmitter systems for induction of pMeCP2. However, to understand whether regulation of specific monoamine neurotransmitter systems is required for the induction of $\mathrm{pMeCP} 2$ following $\mathrm{AMPH}$ administration, we assessed the ability of AMPH to induce $\mathrm{pMeCP} 2$ in the NAc in strains of mice lacking expression of single monoamine transporters (Figure 7).

To determine whether AMPH can induce $\mathrm{pMeCP} 2$ in the NAc in the absence of the DAT, we administered either Veh or $3 \mathrm{mg} / \mathrm{kg}$ AMPH to DAT-KO mice and their DAT-WT 

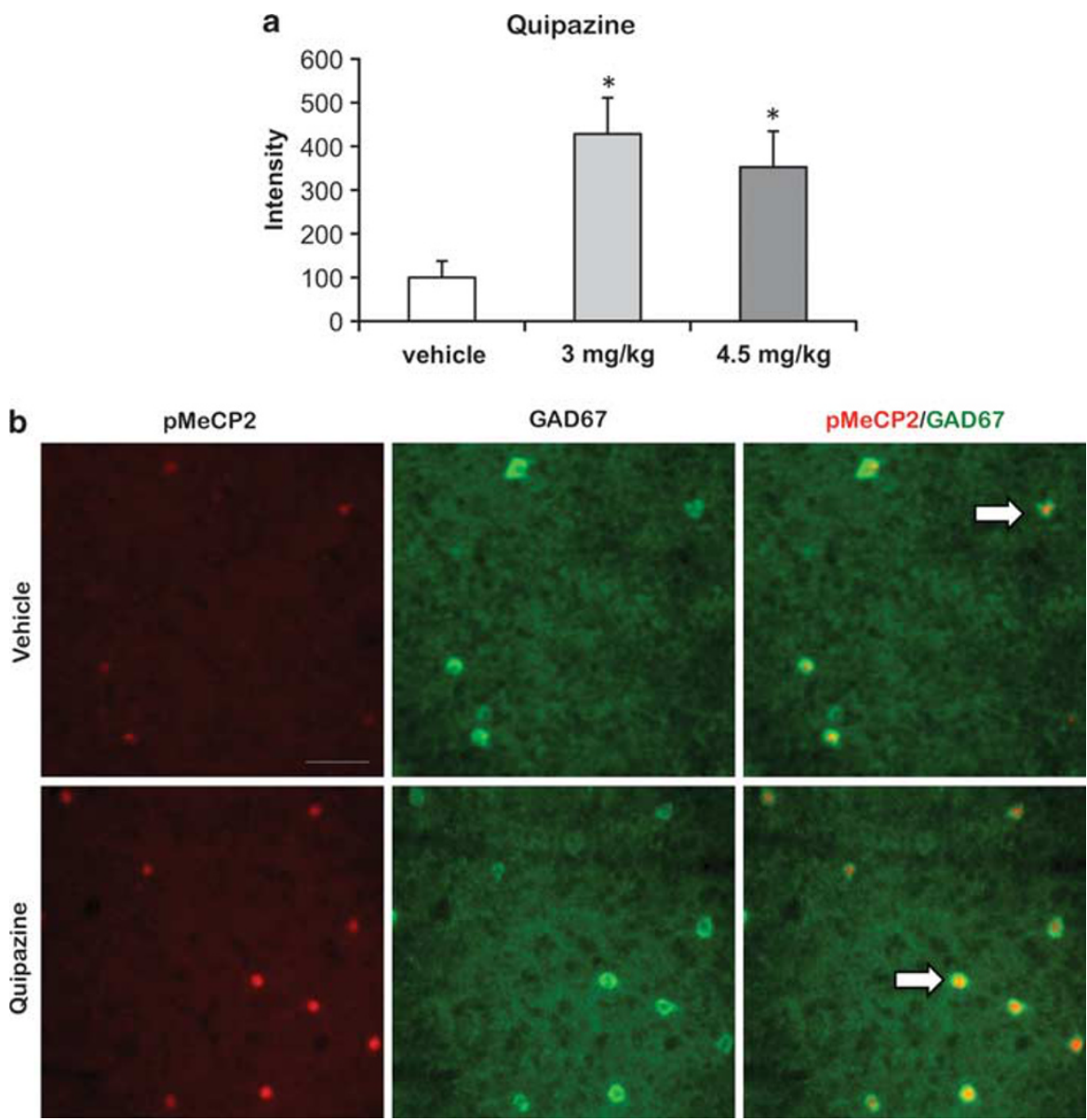

Figure 5 Activation of 5-HT receptors by quipazine induces pMeCP2 in the NAc. (a) Quantitation of pMeCP2 integrated intensity in the NAc $2 \mathrm{~h}$ after treatment with Veh or 3 or $4.5 \mathrm{mg} / \mathrm{kg}$ quipazine. (b) pMeCP2 (red), GAD67 (green), and overlay immunostaining in the NAc $2 \mathrm{~h}$ after treatment with Veh or $3 \mathrm{mg} / \mathrm{kg}$ quipazine. White arrows indicate neurons coimmunolabeled with antibodies for pMeCP2 and GAD67. Values of quantitated immunofluorescence were normalized to Veh control. $n=4-6$ mice/group. $* p<0.05$ compared with Veh. Error bars indicated SEM. Scale bar $=20 \mu \mathrm{m}$.

littermate controls, monitored their activity in the open field for $1 \mathrm{~h}$ post-injection, and then quantified $\mathrm{pMeCP} 2$ in the NAc. A two-way ANOVA applied to locomotor activity $1 \mathrm{~h}$ post-injection revealed an overall main effect of genotype $\left(\mathrm{F}_{3,22}=74.516, \quad p<0.001\right)$, treatment $\left(\mathrm{F}_{3,22}=8.911, p<0.008\right)$, and a significant genotype by treatment interaction $\left(\mathrm{F}_{3,22}=38.785, p<0.001\right)$. Consistent with previous reports (Gainetdinov et al, 1999; Giros et al, 1996), we found that DAT-KO mice had higher levels of baseline locomotor activity $(p<0.001)$ compared with the DAT-WT Veh controls and that their locomotor activity decreased following AMPH exposure $(p<0.001)$ compared with DAT-KO mice given Veh (Figure $7 \mathrm{a}$ ). When an ANOVA was applied to pMeCP2 immunoreactivity, a main effect of treatment $\left(\mathrm{F}_{3,22}=17.709, p<0.001\right)$ was observed. However, there was no effect of genotype $\left(\mathrm{F}_{3,22}=2.082\right.$, $p<0.166)$, and the genotype by treatment interaction was not significant $\left(F_{3,22}=1,192, p<0.289\right)$. Bonferroni corrected pairwise comparisons noted that $\mathrm{pMeCP} 2$ levels were increased by AMPH in both genotypes compared with their Veh-treated controls $(p<0.033$ and $p<0.002$, respectively) (Figure $7 \mathrm{~b}$ ). However, the AMPH-induced levels of pMeCP2 did not differ between DAT-KO mice and their DAT-WT littermates $(p<0.807)$. Although the data did not reach significance, DAT-KO mice showed a trend toward increased basal levels of pMeCP2 compared with DAT-WT mice (Figure $7 \mathrm{~b}$ ), which may arise as a consequence of the increased basal levels of extracellular DA in DAT-KOs (Gainetdinov et al, 1999). Microdialysis studies have shown that psychostimulants can increase extracellular DA levels in the NAc of DAT-KO mice through mechanisms that may involve blockade of the SERT or NET, although the functional relevance of a further increase in extracellular DA in face of the chronic hyperdopaminergia found in this strain remains unclear (Gainetdinov and Caron 2003; Carboni et al, 2001). Nonetheless, since AMPH can also bind the SERT and NET, we next asked whether these transporters are required for AMPH-induced $\mathrm{pMeCP} 2$.

To determine whether $\mathrm{AMPH}$-induced $\mathrm{pMeCP} 2$ in the NAc is impaired in the absence of the SERT or NET, SERTKO and NET-KO mice and their respective WT littermates were treated with Veh or AMPH, locomotor activity was monitored $1 \mathrm{~h}$ post-injection, and subsequently pMeCP2 was quantified in the NAc. For the SERT mice, a two-way ANOVA for locomotor activity revealed only a significant effect of treatment $\left(\mathrm{F}_{3,23}=38.262, p<0.001\right)$. Hence, locomotor activity was stimulated by AMPH to similar extent in both SERT-KO mice and their WT littermates (Figure 7c). 
a
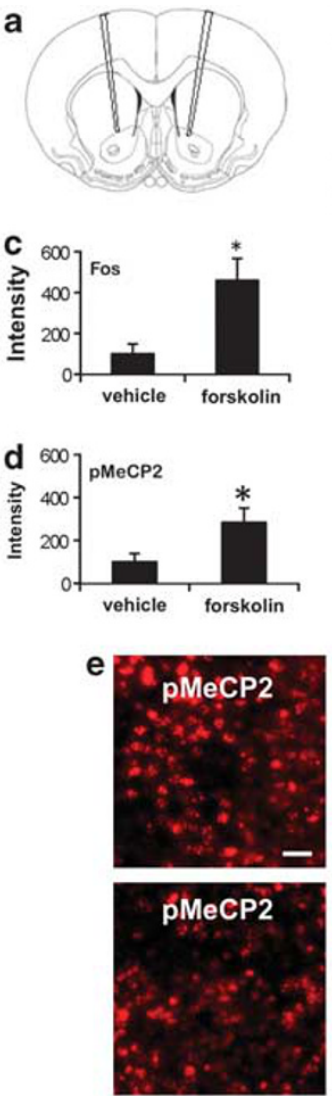

f

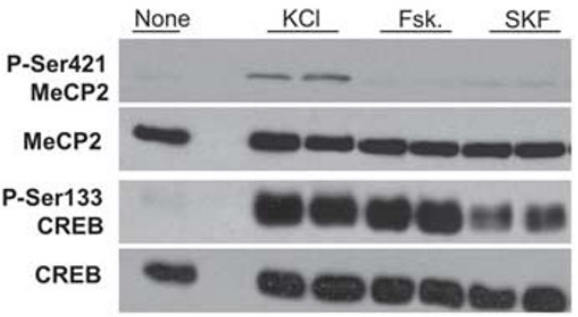

b

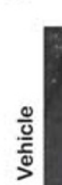

Fos
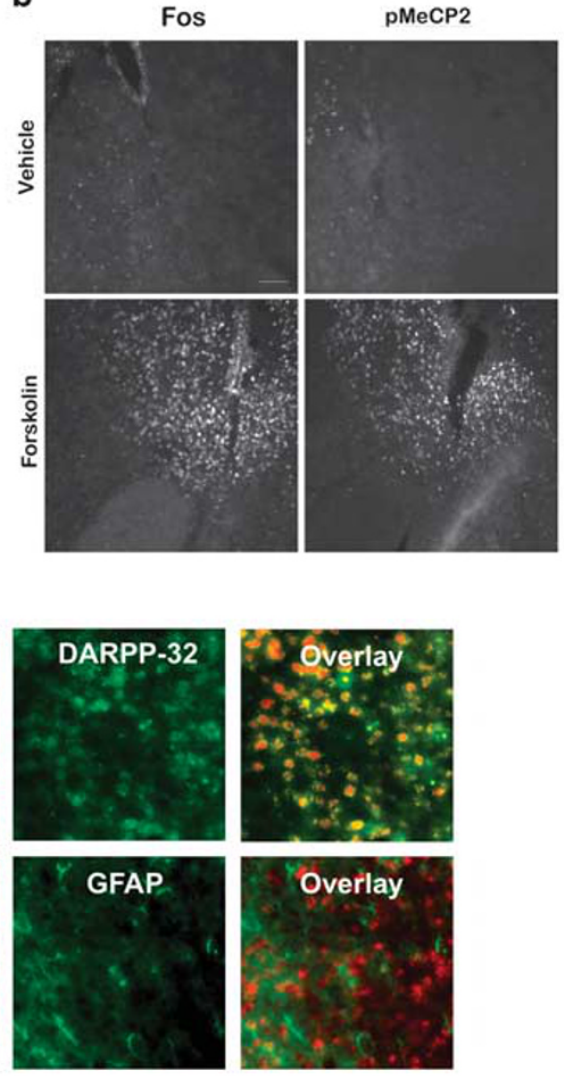

Figure 6 Forskolin is sufficient to induce PMeCP2 in the MSNs in vivo but not in vitro. (a) Anatomical location of microinjection sites in the striatum. (b) PMeCP2 and Fos immunostaining in the striatum 90 min after treatment with Veh or forskolin. (c, d) Quantitation of Fos and pMeCP2 integrated intensity in the striatum $90 \mathrm{~min}$ after treatment with Veh or forskolin. Values of quantitated immunofluorescence were normalized to Veh control. $n=9$ mice/group. * $p<0.05$ compared with Veh. Error bars indicated SEM. (e) Colocalization of pMeCP2 immunoreactivity with cell-type markers in the region at the tip of the cannula in sections from forskolin-treated mice. PMeCP2 (red), the MSN marker DARPP-32 (green, top), the astrocyte marker GFAP (green, bottom). Scale bar $=20 \mu \mathrm{m} .(\mathrm{f}, \mathrm{g})$ Cultured embryonic rat striatal neurons (5 days in vitro) were treated for 60 min with various pharmacological reagents, the cells were lysed directly in boiling SDS and separated by SDS-PAGE, western blotting was performed using the antibodies indicated, and the blots were visualized with chemiluminescence on film. (f) Cultures were left either untreated (none), or treated with $55 \mathrm{mM} \mathrm{KCl}$ in an isotonic solution, $10 \mu \mathrm{M}$ forskolin (Fsk.) to elevate intracellular CAMP, or $50 \mu \mathrm{M}$ of the $\mathrm{D}_{1}$-class DA receptor agonist SKF38393 (SKF). Western blots were probed for PMeCP2 and total MeCP2, or PCREB (Serl33) and total CREB as a control for the activation of cAMP signaling pathways. No protein was loaded in lane 2. (g) Cultures were left either untreated, or treated with $55 \mathrm{mM} \mathrm{KCl}$ or $50 \mu \mathrm{M} \mathrm{NMDA}$ as indicated. In the lanes indicated, the L-type voltage-gated calcium channel inhibitor Nimodipine (Nim.) or the NMDA-receptor antagonist APV was added 2 min before stimulation with NMDA or KCl.

When changes in pMeCP2 were considered, the ANOVA detected significant main effects of genotype $\left(\mathrm{F}_{3,23}=5.542\right.$, $p<0.029)$ and treatment $\left(\mathrm{F}_{3,23}=31.20, p<0.001\right)$, and a significant genotype by treatment interaction $\left(\mathrm{F}_{3,23}=5.467\right.$, $p<0.03)$. Interestingly, Bonferroni comparisons demonstrated that AMPH-induced $\mathrm{pMeCP} 2$ was significantly reduced in SERT-KO mice compared with SERT-WTs $(p<0.003)$, even though AMPH induced locomotor activity to the same extent in both genotypes (Figure $7 \mathrm{~d}$ ). Taken together with our pharmacological studies, the observation that $\mathrm{AMPH}$-induced $\mathrm{pMeCP} 2$ in the NAc is significantly reduced in SERT-KO mice provides independent evidence of a role for 5 -HT signaling in the regulation of $\mathrm{pMeCP} 2$ in the CNS. 

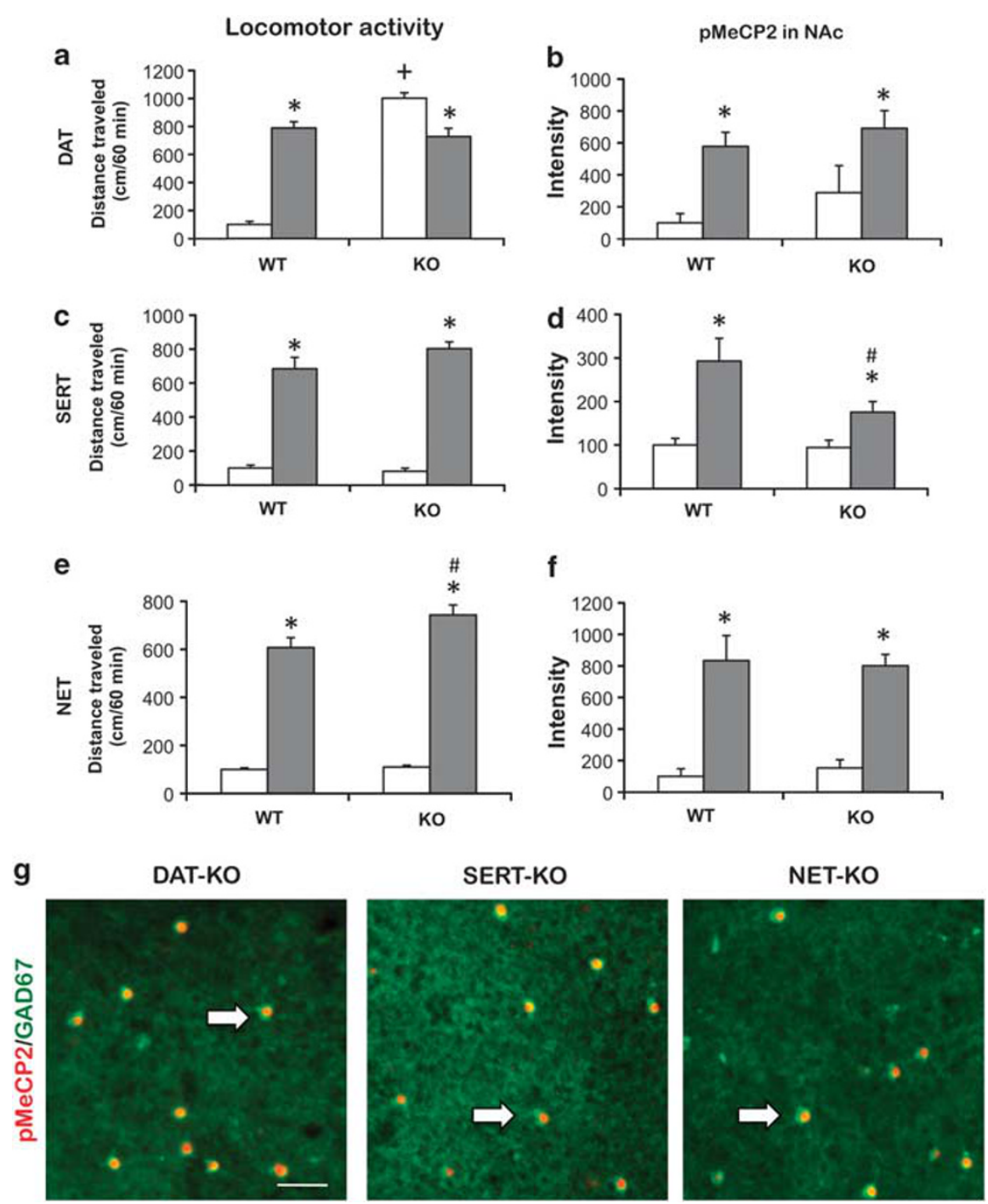

Figure $7 \mathrm{AMPH}$-induced pMeCP2 is reduced in the NAc of SERT-KO mice. (a, c, e) The effects of Veh or AMPH treatment on locomotor activity in DAT, SERT, and NET mice I h post-injection. (b, d, f) pMeCP2 induction in the NAc following Veh or AMPH treatment in DAT, SERT, and NET mice. All values of locomotor activity and quantitated immunofluorescence were normalized to the WT Veh control for each strain of mice. Veh treatment is indicated with a white bar, and AMPH treatment $(3 \mathrm{mg} / \mathrm{kg})$ is indicated with a dark gray bar. $n=6-8$ mice/group. * $p<0.05 \mathrm{AMPH}$ compared with $\mathrm{Veh}$ within the same genotype, ${ }^{+} p<0.05$ WT Veh compared with mutant Veh, ${ }^{*} p<0.05$ WT AMPH compared with mutant AMPH. (g) pMeCP2 (red) and GAD67 (green overlay immunostaining in the NAc $2 \mathrm{~h}$ after treatment with $3 \mathrm{mg} / \mathrm{kg}$ AMPH in the DAT-, SERT-, and NET-KO mice. White arrows indicate neurons coimmunolabeled with antibodies for PMeCP2 and GAD67. Error bars indicate SEM. Scale bar $=20 \mu \mathrm{m}$.

With regards to NET-KO mice, a two-way ANOVA for locomotion revealed a significant effect of genotype $\left(\mathrm{F}_{3,21}=22.008, \quad p<0.001\right)$, treatment $\quad\left(\mathrm{F}_{3,21}=641.144\right.$, $p<0.001)$, and significant treatment by genotype interaction $\left(\mathrm{F}_{3,21}=20.578, p<0.001\right)$. As previously reported (Xu et al, 2000), NET-KO mice were hyperresponsive to the locomotor-stimulating effects of acute AMPH administration compared with their WT littermates $(p<0.001)$ (Figure 7e). By contrast, an ANOVA for pMeCP2 immunoreactivity in the NAc found only a significant effect of treatment $\left(\mathrm{F}_{3,21}=104.690, p<0.001\right)$ (Figure $\left.7 \mathrm{f}\right)$. Therefore, pMeCP2 was normally induced by AMPH in the absence of the NET.

Analysis of AMPH-stimulated pMeCP2 induction within the NAc revealed that in all genotypes tested, pMeCP2 remained selective for GAD67-positive GABAergic interneurons (Figure $7 \mathrm{~g}$ ). These data suggest that no single monoamine neurotransmitter system dictates the cell-type specificity of this pattern of $\mathrm{pMeCP} 2$ induction in the NAc. Furthermore, the evidence that genetic disruption of any single transporter failed to eliminate AMPH-induced pMeCP2 supports our pharmacological evidence that combinatorial signaling through multiple monoamine receptors drives the overall extent and pattern of pMeCP2 induced in the CNS.

\section{pMeCP2 in the NAc Following Repeated AMPH Does Not Predict Behavioral Sensitization}

Beyond providing a means to study the mechanistic actions of pharmacological agents, monoamine transporter KO mice have proven to be useful for investigating the 
physiological functions of monoamine-regulated signaling pathways (Gainetdinov and Caron, 2003). For example, these mice have been used to gain insight into the mechanisms that underlie behavioral sensitization (Rocha, 2003; Xu et al, 2000), which is a progressive and persistent increase in behavioral responses to psychomotor stimulants that develops following their repeated administration (Pierce and Kalivas, 1997). Our previous data revealed a strong correlation between the magnitude of pMeCP2 induced in the NAc and the level of open field locomotor activity following repeated AMPH administration, which is one measure of behavioral sensitization (Deng et al, 2010). To test the hypothesis that pMeCP2 levels in the NAc predict behavioral sensitization to AMPH, we next asked whether pMeCP2 would correlate with locomotor activity following repeated AMPH administration in the NET-KO mice, which fail to sensitize (Xu et al, 2000).
NET-KO and their NET-WT littermates were injected with either Veh or AMPH once daily for 5 consecutive days in their home cages, then following a 7-day withdrawal they were administered an AMPH challenge in the open field to assess locomotor sensitization. The NET-KO mice were significantly more responsive to the locomotorstimulating effects of a single injection of AMPH in this paradigm than similarly treated WT littermates, as we have shown previously (Figure 7c). However, unlike their NETWT littermates, the NET-KO mice failed to exhibit significantly enhanced locomotor activity following repeated AMPH administration $(p<0.0033$ for WT and $p<0.12$ for KO, VEH:AMPH compared with AMPH:AMPH) (Figure $8 \mathrm{a}$ and $\mathrm{b}$ ). When changes in $\mathrm{pMeCP} 2$ were considered, ANOVA failed to detect significant effects of genotype $\left(\mathrm{F}_{3,52}=0.001, p<0.98\right)$ or treatment $\left(\mathrm{F}_{3,52}=0.063\right.$, $p<0.803)$. pMeCP2 in the NAc was induced to similar
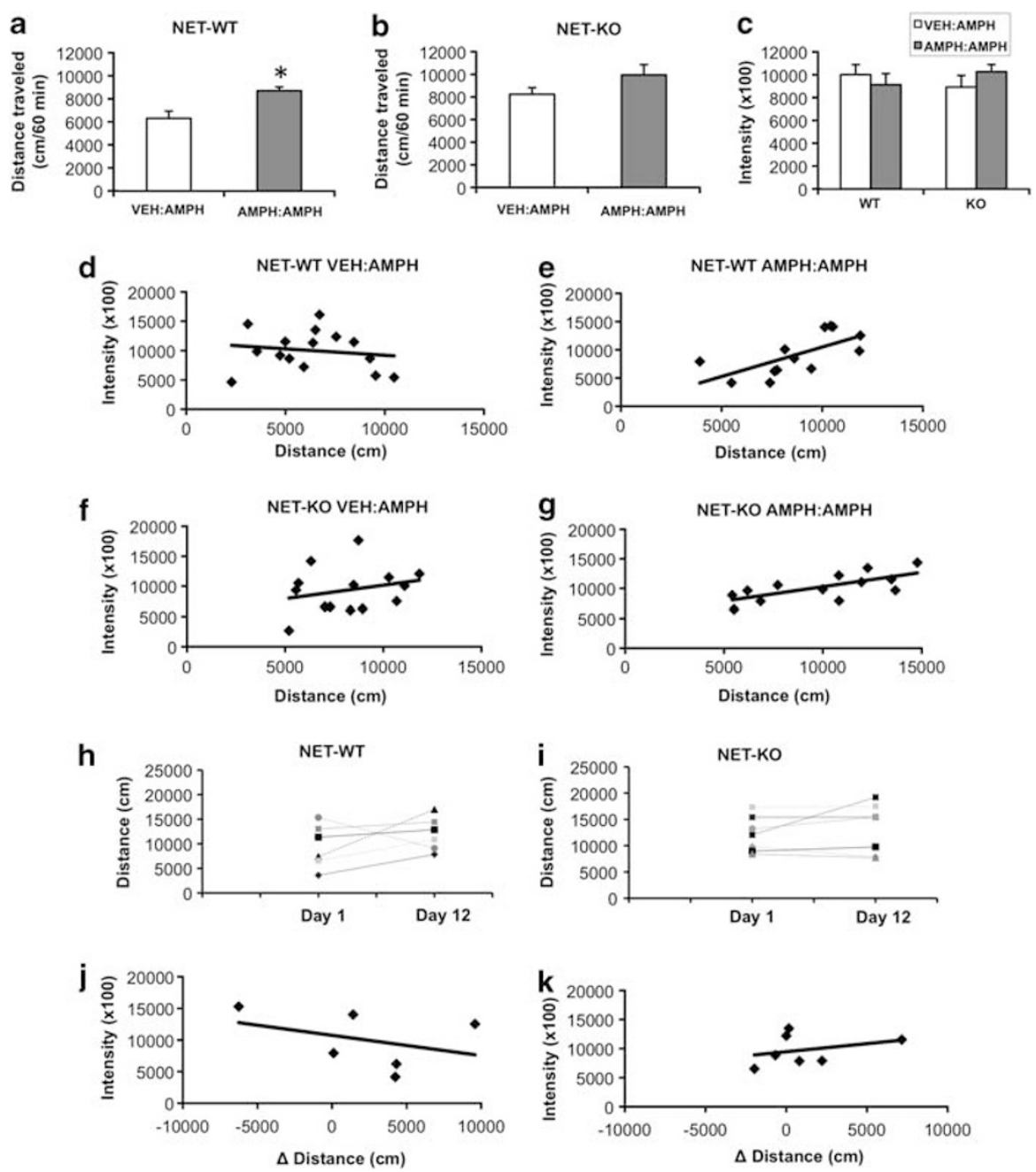

Figure $8 \mathrm{pMeCP} 2$ in the NAc of NET-KO mice correlates with locomotor activity but not behavioral sensitization after repeated AMPH treatment. $(a, b)$ The effects of acute (VEH:AMPH) or repeated (AMPH:AMPH) AMPH administration on locomotor activity in NET-WT and NET-KO mice I $h$ post-injection on the challenge day. (c) pMeCP2 integrated intensity in the NAc following AMPH treatment on the challenge day in NET-WT and NET-KO mice. ( $\mathrm{d}-\mathrm{g})$ Pearson product correlations of $\mathrm{pMeCP} 2$ immunofluorescence intensity in the NAc and cumulative locomotor activity (I h following the challenge injection) from individual mice. ( $h$, i) Comparison of locomotor activity I h post-injection on day I and the challenge day (day I2) in NET-WT and NET-KO mice under the AMPH:AMPH condition. (j, k) Pearson product correlations of PMeCP2 immunofluorescence intensity in the NAc and the change in locomotor activity from day I to day 12 from individual mice in the NET-WT and NET-KO AMPH:AMPH groups. * $p<0.05$ compared with VEH:AMPH. Error bars indicate SEM. 
extents in the two treatment groups (Veh:AMPH or AMPH:AMPH) for each genotype (Figure $8 \mathrm{c}$ ). These data confirm that the lack of NET expression has no effect on the magnitude of pMeCP2 induction following either acute or repeated AMPH exposure, thus allowing us to analyze the correlation between induced $\mathrm{pMeCP} 2$ and locomotor activity in these mice.

Surprisingly, when a correlational analysis was applied to locomotor activity and NAc pMeCP2 induction in individual mice, a marked difference between the acute AMPH (VEH:AMPH) and repeated AMPH (AMPH:AMPH) treatment groups emerged for both NET genotypes (Figure 8d-g). No significant relationship between locomotor activity and pMeCP2 induction was observed in the VEH:AMPH group of either NET-WT $(r=0.16, p=0.578)$ or NET-KO mice $(r=0.25, p=0.379)$ (Figure $8 \mathrm{~d}$ and $\mathrm{f}$ ). By contrast, we observed a strong correlation of pMeCP2 immunoreactivity with locomotor activity in the AMPH:AMPH treatment group of both genotypes $(r=0.67$, $p=0.012$; NET-WT AMPH:AMPH and $r=0.71, p=0.007$ NET-KO AMPH:AMPH) (Figure 8e and g).

Although the level of locomotor activity after repeated AMPH can be used as an indication of behavioral sensitization, this metric does not reveal how the locomotor behavior of any single animal changed over the course of the repeated AMPH treatment. To obtain a more direct measure of locomotor sensitization in individual mice, we measured locomotor responses to AMPH in a different sensitization paradigm in which we monitored open field locomotor activity of each mouse on both the first day of AMPH treatment as well as on the challenge day. This experimental design allowed us to calculate a sensitization score for each mouse by subtracting the locomotor activity on the first day of AMPH treatment from the locomotor activity following AMPH exposure on the challenge day (Figure $8 \mathrm{~h}$ and $\mathrm{i}$ ). When a correlational analysis was applied to sensitization scores and NAc pMeCP2 levels in individual mice, no correlation was seen for either the NET-WT ( $r=0.373, p=0.467$ AMPH:AMPH) or the NET-KO mice $(r=0.314, p=0.492$ AMPH:AMPH) (Figure $8 \mathrm{j}$ and $\mathrm{k}$ ).

Taken together, these data replicate our previous observation that pMeCP2 levels correlate with open field locomotor activity only following repeated and not after acute AMPH. However, the levels of pMeCP2 in the NAc after repeated $A M P H$ administration do not predict the degree of behavioral sensitization in individual mice, at least as measured by open field locomotor activity. An alternate hypothesis suggested by our data is that levels of locomotor activity following repeated AMPH exposure and pMeCP2 levels in the NAc may instead reflect other functional consequences of repeated AMPH treatment that persist in the absence of NET expression.

\section{DISCUSSION}

The net effect of AMPH interactions with monoamine transporters in the CNS is the activation of multiple monoaminergic receptor-coupled signaling pathways, culminating in the induction of intracellular processes including gene expression (Moratalla et al, 1996). Previously, we showed that AMPH administration induces Ser421 phosphorylation of MeCP2 in select populations of neurons within the NAc and PLC. Here, we have characterized the specific monoaminergic neurotransmitter pathways that regulate this phosphorylation event. Our data demonstrate that activation of both DA and 5-HT signaling is sufficient to induce pMeCP2. By contrast, we find no evidence for $\mathrm{NE}$-dependent regulation of $\mathrm{pMeCP} 2$ even though three classes of NE receptors are expressed in the brain, several of which have been implicated in mediating certain aspects of behavioral responses to psychostimulants (Weinshenker and Schroeder, 2007; Xu et al, 2000; Laakso and Hietala, 2000). Although these data do not exclude roles for specific $\mathrm{NE}$ receptor-dependent regulation of $\mathrm{pMeCP} 2$ in other contexts, they do suggest that induction of $\mathrm{pMeCP} 2$ is selective for specific stimuli.

Interestingly, we find that the regional- and cell-type specific pattern of $\mathrm{pMeCP} 2$ induction depends on the particular combination of DA and 5-HT receptors activated. Consistent with the hypothesis that combinatorial signaling through multiple monoamine receptors sculpts the pattern of $\mathrm{pMeCP} 2$ in vivo, we find that genetic disruption of any single plasma membrane monoamine transporter in DATKO, SERT-KO, and NET-KO mice fails to completely block the ability of AMPH to induce pMeCP2 in the NAc and does not change the cell-type selectivity of the induced pattern. Parenthetically, VMAT2 is the other major target of AMPH in the CNS, and although VMAT2-KO mice are not viable after birth, we find that AMPH induces a similar magnitude and pattern of pMeCP2 in the NAc of VMAT2-HETs compared with their VMAT2-WT littermates (data not shown). Analysis of the distribution of pMeCP2 in the CNS following the various pharmacological stimuli used in this study also suggests that no single transporter or receptor expression pattern is sufficient to fully explain the selectivity of pMeCP2 induction. For example, the DAT is highly concentrated in DA-rich brain regions including the neostriatum, NAc, and olfactory tubercle (Ciliax et al, 1995). By contrast, the SERT and NET have more widespread distributions in the brain; high levels of SERT are found in the dorsal striatum, cortex, hippocampus, amygdala, and brainstem (Sur et al, 1996), whereas NET expression is concentrated in the PLC, bed nucleus of stria terminalis, and ventral regions of the striatum, including the NAC (Schroeter et al, 2000). However, only selective inhibition of the DAT induces pMeCP2 in the PLC, even though the SERT and NET are also highly expressed in this brain region (Miner et al, 2000, 2003). Taken together with the failure of either AMPH or the selective DAT inhibitor GBR12909 to induce $\mathrm{pMeCP} 2$ in MSNs of the NAc, which express high levels of DA receptors, these data suggest that either combinatorial patterns of transporter and receptor expression or additional mechanisms of specificity are important for the regulation of $\mathrm{pMeCP} 2$.

Our data suggest that one way different combinations of DA and 5-HT receptors influence the cell-type specific phosphorylation of $\mathrm{MeCP} 2$ is via the integration of receptor-induced signaling cascades at the level of cAMP. Both $\mathrm{D}_{1}$ - and $\mathrm{D}_{2}$-class $\mathrm{DA}$ receptors as well as most types of 5-HT receptors are coupled by G-proteins to the regulation of adenylate cyclase and cAMP signaling (Barnes and Sharp, 1999; Missale et al, 1998). $\mathrm{D}_{1}$-class DA receptors elevate cAMP levels and we find that they drive widespread 
induction of pMeCP2 both in MSNs within the NAc and in other brain regions including the hippocampus. $\mathrm{D}_{2}$-class DA receptors inhibit cAMP production and we see that they oppose the $\mathrm{D}_{1}$-class $\mathrm{DA}$ receptor-dependent induction of pMeCP2 in MSNs and hippocampal neurons. Elevation of cAMP levels leads to the activation of intracellular signaling cascades that can directly regulate nuclear signaling events, such as the induction of PKA-dependent Ser133 phosphorylation on the transcription factor CREB (Yamamoto et al, 1988). However, MeCP2 Ser421 is not a direct target of phosphorylation by PKA (Zhou et al, 2006). Instead, calcium-calmodulin-activated kinases (CaMKII or CaMKIV) have been identified as the likely MeCP2 Ser421 kinases following the activation of NMDA-type glutamate receptors and the opening of L-type voltage-gated calcium channels (Tao et al, 2009; Zhou et al, 2006). It is possible that $\mathrm{DA}$ and $5-\mathrm{HT}$ receptors could induce $\mathrm{pMeCP} 2$ via the regulation of intracellular calcium levels. $\mathrm{G}_{\mathrm{q} / 11}$-coupled $\mathrm{DA}$ and 5-HT receptors can release calcium from intracellular stores (Missale et al, 1998), and the $5-\mathrm{HT}_{3}$ receptor is unique in that it is a ligand-gated ion channel directly permeable to calcium (Derkach et al, 1989). Activation of $\mathrm{D}_{1}$-class $\mathrm{DA}$ receptors in cultured striatal neurons can elevate intracellular calcium levels indirectly through a mechanism that may involve DA- and PKA-dependent phosphorylation of the NR1 subunit of the NMDA-type glutamate receptor (Dudman et al, 2003). Stimulation of $\mathrm{D}_{1^{-}}$ class DA receptors also leads to PKA-dependent potentiation of L-type voltage-gated calcium channels in striatal neurons (Surmeier et al, 1995), and the subsequent activation of CaMKII by this pathway has been shown to be required for the regulation of AMPA-type glutamate receptor trafficking in the NAc in vivo in a cocaine-seeking paradigm (Anderson et al, 2008).

In addition to these postsynaptic sites of DA and 5-HT receptor action, our data raise the possibility that the induction of pMeCP2 in MSNs may be modulated by cAMPregulated processes in presynaptic terminals of afferent neurons that project to the striatum. Forskolin has been widely shown to enhance presynaptic vesicle release probability (Robbe et al, 2001; Chen and Regehr, 1997; Chavez-Noriega and Stevens, 1994). In striatal slice preparations, DA-dependent modulation of glutamate release from corticostriatal terminals allows for filtering of less active inputs and reinforcement of specific sets of corticostriatal synaptic connections (Bamford et al, 2004). Application of AMPH to this preparation inhibits presynaptic vesicle release from corticostriatal glutamatergic terminals in a manner that depends on $\mathrm{D}_{2}$-class $\mathrm{DA}$ receptors (Bamford et al, 2004). Since NMDA-type glutamate receptors are robust activators of pMeCP2 in MSNs (Figure $6 \mathrm{~g}$ ), we propose that the inhibition of glutamate release by $D_{2}$-class receptors may underlie the ability of $D_{2}$-class receptor agonists to inhibit the $D_{1}$-class agonist induction of $\mathrm{pMeCP} 2$ in this population of neurons.

One commonality we observed among all of the DA and 5 -HT reagents tested in this study is their ability to induce robust pMeCP2 in GAD67-positive GABAergic interneurons of the NAc. Although the signaling mechanisms that mediate this induction remain to be fully established, several lines of evidence suggest that this may reflect increases in firing of this cell population. In vivo recordings from presumed GAD67-positive striatal GABAergic interneurons in freely moving rats demonstrate that $\mathrm{AMPH}$ administration induces a rapid increase in the firing rate of most of these neurons (Wiltschko et al, 2010). $\mathrm{D}_{2}$-class receptors appear to play an important facilitative role in this excitability because administration of the $\mathrm{D}_{2}$-class receptor agonist eticlopride uniformly decreases the firing rate of these cells (Wiltschko et al, 2010). DA and 5-HT could act directly on GAD67-positive GABAergic interneurons to modulate their activity. Striatal GABAergic interneurons have been shown to express and be excited by $D_{1}$-class DA receptors; in slice preparations they are also activated indirectly through actions of presynaptic $\mathrm{D}_{2}$-class receptors (Centonze et al, 2003; Bracci et al, 2002). Application of 5 -HT to striatal slices also increases firing of GABAergic interneurons via activation of $5-\mathrm{HT}_{2 \mathrm{C}}$ receptors (Blomeley and Bracci, 2009). Alternatively, DA and 5-HT could modulate properties of the afferent inputs to the striatum in a manner that changes the drive to GAD67-positive GABAergic interneurons. Excitatory input to GAD67positive GABAergic interneurons in the NAc comes from the prefrontal cortex (Gruber et al, 2009), while the major source of GABAergic inhibitory feedback onto these neurons comes from the globus pallidus (Bevan et al, 1998). $D_{2}$-receptor antagonists enhance the expression of Fos in the globus pallidus (Billings and Marshall, 2003), suggesting that increased firing of globus pallidus neurons induced by $\mathrm{D}_{2}$ blockade could contribute to the suppression in striatal GABAergic interneuron firing described above (Wiltschko et al, 2010). Increased firing of GABAergic interneurons would lead to the opening of voltage-gated calcium channels, thus activating the CaM kinases that phosphorylate MeCP2. Although GABAergic interneurons are not thought to express the $\alpha$ isoform of CaMKII (Liu and Jones, 1996), the $\beta, \gamma$, and $\delta$ isoforms are widely expressed throughout the brain although at much lower levels than CaMKII $\alpha$ (Sakagami and Kondo, 1993; Tighilet et al, 1998). Interestingly, a subset of hippocampal GABAergic interneurons have been shown to have an NMDA-receptordependent form of long-term potentiation that is blocked by $\mathrm{CaM}$ kinase inhibitors, suggesting the functional importance of non- $\alpha$ isoform-mediated CaMKII activity in these neurons (Lamsa et al, 2007).

Our behavioral data yield some insights into the functional implications of pMeCP2 induction. First, although the induction of pMeCP2 in the NAc is concurrent with the increase in locomotor activity following acute AMPH administration, $\mathrm{pMeCP} 2$ coincides with decreased locomotor activity following acute citalopram and with the paradoxical decrease in locomotor activity following AMPH administration in DAT-KO mice. Furthermore, following a single dose of $A M P H$, there is no correlation between the level of pMeCP2 induced in the NAc and the locomotor activity of an individual animal (Deng et al, 2010). Thus, pMeCP2 induction in the NAc reflects the effects of these drugs on the brain that are not directly involved in determining or sensing the level of locomotor activity. Interestingly, $\mathrm{pMeCP} 2$ in the $\mathrm{NAc}$ does correlate with locomotor activity following repeated AMPH treatment. Locomotor activity after repeated AMPH exposure is one measure of behavioral sensitization, which presumably occurs as a result of psychostimulant-induced neural circuit 
adaptations, although these remain poorly defined (Kauer and Malenka, 2007). However, pMeCP2 still correlates with locomotor activity following repeated AMPH treatment in NET-KO mice, which do not sensitize. Importantly, although the NET-KO mice do not sensitize to repeated AMPH administration, they do show other behavioral adaptations to repeated psychostimulant administration. For example, the NET-KO mice show preference for the cocaine-paired chamber in a CPP assay (Xu et al, 2000), and they self-administer cocaine in a dose-dependent manner (Rocha, 2003). Thus, we hypothesize that pMeCP2 induction may reflect the neural circuit activities that underlie these or other related behavioral adaptations to repeated AMPH exposure. Because the phosphorylation of pMeCP2 is selective for GABAergic interneurons of the NAc following AMPH and many of the other drugs tested here, it is tempting to speculate that $\mathrm{pMeCP} 2$ may play a role in plasticity of this neuronal population. It should be emphasized that the functions of GAD67-positive GABAergic striatal interneurons in behavioral responses to AMPH are entirely unknown. However, these cells exert robust feedforward inhibition over striatal output (Koos and Tepper, 1999), and changes in their firing patterns have been suggested to underlie the initiation of chosen actions while suppressing unwanted alternatives (Gage et al, 2010).

Finally, a novel finding of our study is the observation that the selective SERT inhibitor citalopram is sufficient to induce pMeCP2 in the CNS. 5-HT depletion has been shown to significantly reduce the inflammation-induced phosphorylation of MeCP2 in sensory neurons of the dorsal horn of the spinal cord (Geranton et al, 2008). Together with our findings, these data raise the possibility that serotonergic regulation of $\mathrm{pMeCP} 2$ could be important in a range of experimental paradigms and cell types. Drugs that target the SERT and 5-HT receptors are widely used in treating neuropsychiatric disorders such as depression (Krishnan and Nestler, 2008; Morilak and Frazer, 2004; Charney, 1998). In rodents, serotonergic regulation of affective behaviors has been shown in social-defeat stress and extended social isolation (Wallace et al, 2009; Tsankova et al, 2006), and drugs that alter serotonergic transmission modulate depressive-like behavior in these paradigms through mechanisms that are thought to involve changes in gene transcription (Vialou et al, 2010; Wallace et al, 2009; Tsankova et al, 2006; Nestler and Carlezon, 2006). Our evidence that a selective SERT inhibitor induces pMeCP2 in neural circuits that are functionally relevant to affective behaviors raises the possibility that this pathway could be involved in the mechanism of antidepressant action. From this perspective, investigating the regulation of $\mathrm{pMeCP} 2$ in the response to chronic antidepressant treatment may yield new insights into additional functional roles for MeCP2 in monoamine-regulated neural plasticity.

\section{ACKNOWLEDGEMENTS}

We thank MG Caron for generously sharing the DAT, NET, and VMAT2 mice and FS Hall for kindly supplying the SERT mice. We also thank RM Rodriguiz for technical assistance. Support for this work was provided by National Institute of Drug Abuse grants R01-DA022202 (AEW) and F32-DA025447 (JVD).

\section{DISCLOSURE}

The authors declare that this work was funded by NIH and that over the past three years WCW has received research funds from Abbott Laboratories, whose research objective was unrelated to the work contained within the present manuscript.

\section{REFERENCES}

Anderson SM, Famous KR, Sadri-Vakili G, Kumaresan V, Schmidt HD, Bass CE et al (2008). CaMKII: a biochemical bridge linking accumbens dopamine and glutamate systems in cocaine seeking. Nat Neurosci 11: 344-353.

Bamford NS, Zhang H, Schmitz Y, Wu NP, Cepeda C, Levine MS et al (2004). Heterosynaptic dopamine neurotransmission selects sets of corticostriatal terminals. Neuron 42: 653-663.

Barnes NM, Sharp T (1999). A review of central 5-HT receptors and their function. Neuropharmacol 38: 1083-1152.

Bevan MD, Booth PA, Eaton SA, Bolam JP (1998). Selective innervation of neostriatal interneurons by a subclass of neuron in the globus pallidus of the rat. J Neurosci 18: 9438-9452.

Billings LM, Marshall JF (2003). D2 antagonist-induced c-fos in an identified subpopulation of globus pallidus neurons by a direct intrapallidal action. Brain Res 964: 237-243.

Blomeley CP, Bracci E (2009). Serotonin excites fast-spiking interneurons in the striatum. Eur J Neurosci 29: 1604-1614.

Bracci E, Centonze D, Bernardi G, Calabresi P (2002). Dopamine excites fast-spiking interneurons in the striatum. J Neurophysiol 87: 2190-2194.

Carboni E, Spielewoy C, Vacca C, Nosten-Bertrand M, Giros B, Di Chiara G (2001). Cocaine and amphetamine increase extracellular dopamine in the nucleus accumbens of mice lacking the dopamine transporter gene. J Neurosci 21: 1-4.

Centonze D, Grande C, Saulle E, Martin AB, Gubellini P, Pavon N et al (2003). Distinct roles of D1 and D5 dopamine receptors in motor activity and striatal synaptic plasticity. J Neurosci 23: 8506-8512.

Charney DS (1998). Monoamine dysfunction and the pathophysiology and treatment of depression. J Clin Psychiatry 59: 11-14.

Chavez-Noriega LE, Stevens CF (1994). Increased transmitter release at excitatory synapses produced by direct activation of adenylate cyclase in rat hippocampal slices. J Neurosci 14: 310-317.

Chen C, Regehr WG (1997). The mechanism of cAMPmediated enhancement at a cerebellar synapse. J Neurosci 17: 8687-8694.

Chen WG, Chang Q, Lin Y, Meissner A, West AE, Griffith EC et al (2003). Derepression of BDNF transcription involves calcium-dependent phosphorylation of MeCP2. Science 302: 885-889.

Ciliax BJ, Heilman C, Demchyshyn LL, Pristupa ZB, Ince E, Hersch SM et al (1995). The dopamine transporter: immunochemical characterization and localization in the brain. J Neurosci 15 (3 Pt 1): 1714-1723.

Deng JV, Rodriguiz RM, Hutchinson AN, Kim IH, Wetsel WC, West AE (2010). MeCP2 in the nucleus accumbens contributes to neural and behavioral responses to psychostimulants. Nat Neurosci 13: 1128-1136.

Derkach V, Surprenant A, North RA (1989). 5-HT3 receptors are membrane ion channels. Nature 339: 706-709.

Dudman JT, Eaton ME, Rajadhyaksha A, Macias W, Taher M, Barczak A et al (2003). Dopamine Dl receptors mediate CREB phosphorylation via phosphorylation of the NMDA receptor at Ser897-NR1. J Neurochem 87: 922-934. 
Fleckenstein AE, Volz TJ, Riddle EL, Gibb JW, Hanson GR (2007). New insights into the mechanism of action of amphetamines. Annu Rev Pharmacol Toxicol 47: 681-698.

Gage GJ, Stoetzner CR, Wiltschko AB, Berke JD (2010). Selective activation of striatal fast-spiking interneurons during choice execution. Neuron 67: 466-479.

Gainetdinov RR, Caron MG (2003). Monoamine transporters: from genes to behavior. Annu Rev Pharmacol Toxicol 43: 261-284.

Gainetdinov RR, Wetsel WC, Jones SR, Levin ED, Jaber M, Caron MG (1999). Role of serotonin in the paradoxical calming effect of psychostimulants on hyperactivity. Science 283: 397-401.

Geranton SM, Fratto V, Tochiki KK, Hunt SP (2008). Descending serotonergic controls regulate inflammation-induced mechanical sensitivity and methyl-CpG-binding protein 2 phosphorylation in the rat superficial dorsal horn. Mol Pain 4: 35-45.

Giros B, Jaber M, Jones SR, Wightman RM, Caron MG (1996). Hyperlocomotion and indifference to cocaine and amphetamine in mice lacking the dopamine transporter. Nature 379: 606-612.

Gruber AJ, Powell EM, O'Donnell P (2009). Cortically activated interneurons shape spatial aspects of cortico-accumbens processing. J Neurophysiol 101: 1876-1882.

Han DD, Gu HH (2006). Comparison of the monoamine transporters from human and mouse in their sensitivities to psychostimulant drugs. BMC Pharmacol 6: 6 .

Hyman SE, Malenka RC, Nestler EJ (2006). Neural mechanisms of addiction: the role of reward-related learning and memory. Annu Rev Neurosci 29: 565-598.

Im H, Hollander JA, Bali P, Kenney PJ (2010). MeCP2 controls BDNF expression and cocaine intake through homeostatic interactions with microRNA-212. Nat Neurosci 13: 1120-1127.

Kauer JA, Malenka RC (2007). Synaptic plasticity and addiction. Nat Rev Neurosci 8: 844-858.

Koos T, Tepper JM (1999). Inhibitory control of neostriatal projection neurons by GABAergic interneurons. Nat Neurosci 2: 467-472.

Krishnan V, Nestler EJ (2008). The molecular neurobiology of depression. Nature 455: 894-902.

Kumar A, Choi KH, Renthal W, Tsankova NM, Theobald DE, Truong HT et al (2005). Chromatin remodeling is a key mechanism underlying cocaine-induced plasticity in striatum. Neuron 48: 303-314.

Laakso A, Hietala J (2000). PET studies of brain monoamine transporters. Curr Pharm Des 6: 1611-1623.

Lamsa K, Irvine EE, Giese KP, Kullmann DM (2007). NMDA receptor-dependent long-term potentiation in mouse hippocampal interneurons shows a unique dependence on $\mathrm{Ca}(2+)$ / calmodulin-dependent kinases. J Physiol 584(Pt 3): 885-894.

Liu XB, Jones EG (1996). Localization of alpha type II calcium calmodulin-dependent protein kinase at glutamatergic but not gamma-aminobutyric acid (GABAergic) synapses in thalamus and cerebral cortex. Proc Natl Acad Sci 93: 7332-7336.

Maze I, Covington III HE, Dietz DM, LaPlant Q, Renthal W, Russo $\mathrm{SJ}$ et al (2010). Essential role of the histone methyltransferase G9a in cocaine-induced plasticity. Science 327: 213-216.

Miner LH, Schroeter S, Blakely RD, Sesack SR (2000). Ultrastructural localization of the serotonin transporter in superficial and deep layers of the rat prelimbic prefrontal cortex and its spatial relationship to dopamine terminals. J Comp Neurol 427: 220-234.

Miner LH, Schroeter S, Blakely RD, Sesack SR (2003). Ultrasturctural localization of the norepinephrine transporter in superficial and deep layers of the rat prelimbic prefrontal cortex and its spatial relationship to probable dopamine terminals. J Comp Neurol 466: 478-494.

Missale C, Nash SR, Robinson SW, Jaber M, Caron MG (1998). Dopamine receptors: from structure to function. Physiol Rev 78: 189-225.
Miyata S, Hamamura T, Lee Y, Miki M, Habara T, Oka T et al (2005). Contrasting Fos expression induced by acute reboxetine and fluoxetine in the rat forebrain: neuroanatomical substrates for the antidepressant effect. Psychopharmacology 177: 289-295.

Moratalla R, Elibol B, Vallejo M, Graybiel AM (1996). Networklevel changes in expression of inducible Fos-Jun proteins in the striatum during chronic cocaine treatment and withdrawal. Neuron 17: 147-156.

Morilak DA, Frazer A (2004). Antidepressants and brain monoaminergic systems: a dimensional approach to understanding their behavioural effects in depression and anxiety disorders. Int J Neuropsychopharmacol 7: 193-218.

Nan X, Ng HH, Johnson CA, Laherty CD, Turner BM, Eisenman $\mathrm{RN}$ et al (1998). Transcriptional repression by the methyl-CpGbinding protein MeCP2 involves a histone deacetylase complex. Nature 393: 386-389.

Nestler EJ (2008). Transcriptional mechanisms of addiction: role of $\Delta$ FosB. Philos Trans R Soc Lond B Biol Sci 363: 3245-3255.

Nestler EJ, Carlezon Jr WA (2006). The mesolimbic dopamine reward circuit in depression. Biol Psychiatry 59: 1151-1159.

Pierce RC, Kalivas PW (1997). A circuitry model of the expression of behavioral sensitization to amphetamine-like psychostimulants. Brain Res Brain Res Rev 25: 192-216.

Renthal W, Kumar A, Xiao G, Wilkinson M, Covington III HE, Maze I et al (2009). Genome-wide analysis of chromatin regulation by cocaine reveals a role for sirtuins. Neuron 62: 335-348.

Robbe D, Alonso G, Duchamp F, Bockaert J, Manzoni OJ (2001). Localization and mechanisms of action of cannabinoid receptors at the glutamatergic synapses of the mouse nucleus accumbens. J Neurosci 21: 109-116.

Rocha BA (2003). Stimulant and reinforcing effects of cocaine in monoamine transporter knockout mice. Eur J Pharmacol 479: 107-115.

Sakagami H, Kondo H. (1993). Differential expression of mRNAs encoding gamma and delta subunits of Ca2+/calmodulindependent protein kinase type II (CaM kinase II) in the mature and postnatally developing rat brain. Brain Res Mol Brain Res 20: 51-63.

Schroeter S, Apparsundaram S, Wiley RG, Miner LH, Sesack SR, Blakely RD (2000). Immunolocalization of the cocaine- and antidepressant-sensitive l-norepinephrine transporter. J Comp Neurol 420: 211-232.

Sulzer D, Sonders MS, Poulsen NW, Galli A (2005). Mechanisms of neurotransmitter release by amphetamines: a review. Prog Neurobiol 75: 406-433.

Sur C, Betz H, Schloss P (1996). Localization of the serotonin transporter in rat spinal cord. Eur J Neurosci 8: 2753-2757.

Surmeier DJ, Bargas J, Hemmings Jr HC, Nairn AC, Greengard P (1995). Modulation of calcium currents by a D1 dopaminergic protein kinase/phosphatase cascade in rat neostriatal neurons. Neuron 14: 385-397.

Tao J, Hu K, Chang Q, Wu H, Sherman NE, Martinowich K et al (2009). Phosphorylation of MeCP2 at Serine 80 regulates its chromatin association and neurological function. Proc Natl Acad Sci 106: 4882-4887.

Tao X, Finkbeiner S, Arnold DB, Shaywitz AJ, Greenberg ME (1998). Ca2+ influx regulates BDNF transcription by a CREB family transcription factor-dependent mechanism. Neuron 20: 709-726.

Tighilet B, Hashikawa T, Jones EG (1998). Cell- and lamina-specific expression and activity-dependent regulation of type II calcium/ calmodulin-dependent protein kinase isoforms in monkey visual cortex. J Neurosci 18: 2129-2146.

Tsankova NM, Berton O, Renthal W, Kumar A, Neve RL, Nestler EJ (2006). Sustained hippocampal chromatin regulation in a mouse model of depression and antidepressant action. Nat Neurosci 9: 519-525. 
Vialou V, Robison AJ, Laplant QC, Covington III HE, Dietz DM, Ohnishi YN et al (2010). Delta FosB in brain reward circuits mediates resilience to stress and antidepressant responses. Nat Neurosci 13: 745-752.

Wallace DL, Han MH, Graham DL, Green TA, Vialou V, Iniguez SD et al (2009). CREB regulation of nucleus accumbens excitability mediates social isolation-induced behavioral deficits. Nat Neurosci 12: 200-209.

Weinshenker D, Schroeder JP (2007). There and back again: a tale of norepinephrine and drug addiction. Neuropsychopharmacology 32: 1433-1451.

Wiltschko AB, Pettibone JR, Berke JD (2010). Opposite effects of stimulant and antipsychotic drugs on striatal fast-spiking interneurons. Neuropsychopharmacology 35: 1261-1270.
Xu F, Gainetdinov RR, Wetsel WC, Jones SR, Bohn LM, Miller GW et al (2000). Mice lacking the norepinephrine transporter are supersensitive to psychostimulants. Nat Neurosci 3: 465-471.

Xu M, Koeltzow TE, Santiago GT, Moratalla R, Cooper DC, Hu XT et al (1997). Dopamine D3 receptor mutant mice exhibit increased behavioral sensitivity to concurrent stimulation of D1 and D2 receptors. Neuron 19: 837-848.

Yamamoto KK, Gonzalez GA, Biggs III WH, Montminy MR (1988). Phosphorylation-induced binding and transcriptional efficacy of nuclear factor CREB. Nature 334: 494-498.

Zhou Z, Hong EJ, Cohen S, Zhao WN, Ho HY, Schmidt L et al (2006). Brain-specific phosphorylation of $\mathrm{MeCP} 2$ regulates activity-dependent Bdnf transcription, dendritic growth, and spine maturation. Neuron 52: 255-269. 